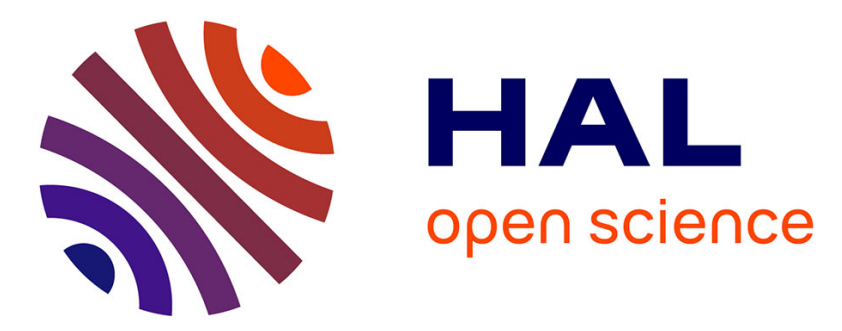

\title{
Archaeological ochres of the rock art site of Leopard Cave (Erongo, Namibia): looking for Later Stone Age socio-cultural behaviours
}

G. Mauran, M. Lebon, O. Lapauze, F. Detroit, J.-J. Bahain, D. Pleurdeau, A. Nankela, J. Lesur

\section{To cite this version:}

G. Mauran, M. Lebon, O. Lapauze, F. Detroit, J.-J. Bahain, et al.. Archaeological ochres of the rock art site of Leopard Cave (Erongo, Namibia): looking for Later Stone Age socio-cultural behaviours. African Archaeological Review, 2020, 10.1007/s10437-020-09394-7 . hal-02568815

\section{HAL Id: hal-02568815 https://hal.science/hal-02568815}

Submitted on 6 Mar 2021

HAL is a multi-disciplinary open access archive for the deposit and dissemination of scientific research documents, whether they are published or not. The documents may come from teaching and research institutions in France or abroad, or from public or private research centers.
L'archive ouverte pluridisciplinaire HAL, est destinée au dépôt et à la diffusion de documents scientifiques de niveau recherche, publiés ou non, émanant des établissements d'enseignement et de recherche français ou étrangers, des laboratoires publics ou privés.

\section{(1)(1) $\$(0)$}

Distributed under a Creative Commons Attribution - NonCommercial - ShareAlikel 4.0 


\title{
Archaeological Ochres of the Rock Art Site of Leopard Cave (Erongo, Namibia): Looking for Later Stone Age Sociocultural Behaviors
}

G. Mauran (*) : M. Lebon : O. Lapauze : F. Détroit : J.J. Bahain : D. Pleurdeau UMR7194 Histoire Naturelle de l'Homme Préhistorique (HNHP), Muséum national d'Histoire naturelle, CNRS, Université Perpignan Via Domitia, Alliance Sorbonne Université - Musée de l'Homme, 17 Place du Trocadéro, 75116 Paris, France

A. Nankela

Archaeology Unit, National Heritage Council of Namibia, 153, Dr. AB May \& Rev. Michael Scott Streets, Ausspannplatz, Windhoek, Namibia

J. Lesur

UMR 7209 Archéozoologie, Archéobotanique, Sociétés, Pratiques et Environnements (AASPE), Muséum

National d'Histoire Naturelle, CNRS, Alliance Sorbonne Université, 55 rue Buffon, 75005 Paris, France

*e-mail: guilhem.mauran1@edu.mnhn.fr

Electronic supplementary material The online version of this article (https://doi.org/10.1007/s10437-020-09394-7) contains supplementary material.

To cite this article: Mauran, G., Lebon, M., Lapauze, O. et al. Archaeological Ochres of the Rock Art Site of Leopard Cave (Erongo, Namibia): Looking for Later Stone Age Sociocultural Behaviors. Afr Archaeol Rev 37, 527-550 (2020). https://doi.org/10.1007/s10437-020-09394-7

\begin{abstract}
The use of ochre has been documented in many Middle Stone Age sites of Southern Africa. However, the literature on the exploitation of ochre within the archaeo-logical contexts of Later Stone Age (LSA) rock art sites is scarce. Despite the discovery of several painted shelters within the Erongo Mountains (Namibia), no archaeologi-cal study of ochre assemblages has been conducted in the region. Here, we present the archaeological ochre assem-blage recovered from a LSA sequence at the rock art shelter of Leopard Cave (Erongo, Namibia), spanning ca. 5,700 to 2,100 cal. BP. The use-wear traces present on some ochre fragments and the stone tools bearing red residues are indicative of different stages of ochre process-ing at the site. The presence of other artifacts, such as ostrich eggshell and bone beads with red residues, and the existence of rock paintings in the cave are pointers to the importance of ochre for understanding the sociocultural behaviors of the LSA populations in central Namibia.
\end{abstract}

Résumé Bien que de nombreux sites du Middle Stone Age d'Afrique australe documentent l'utilisation de matières colorantes ferrugineuses, la littérature existante sur leur utilisation dans des contextes archéologiques de sites d'art rupestre du Later Stone Age (LSA) est rare. Malgré la découverte de plusieurs abris ornés riches de nombreux blocs de matières colorantes ferrugineuses dans les monts Erongo (Namibie), aucune étude n'a été mené sur ces matières premières dans cette région. Nous présentons dans cet article l'assemblage archéologique de matières colorantes ferrugineuses récupérées dans l'abri orné de Leopard Cave (Erongo, Namibie) au sein d'newapos;une séquence LSA, s'étendant d'environ 5700 à 2100 cal. a. BP. Les traces d'utilisations présentes sur certains blocs de matières colorantes ferrugineuses et la présence d'outils en pierre portant des traces de résidus rouges à leur surface attestent de l'existence de différentes « chaînes opératoires » de traitement des matières colorantes ferrugineuses sur le site. La présence d'autres artefacts portant des traces de résidus rouges tels que des perles en coquille d'oeuf d'autruche ou en os et l'existence dans l'abri de peintures rupestres soulignent l'importance d'étudier les matières colorantes pour comprendre les comportements socio-culturels des populations LSA en Namibie centrale.

Keywords Later Stone Age ${ }^{\circ} \operatorname{Ochre}{ }^{\text {Rock art }}{ }^{\star}$ Erongo ${ }^{`}$ Namibia ${ }^{`}$ chaîne opératoire 


\section{Introduction}

Ochre is the common archaeological name of ferrugi-nous rocks and iron oxides with a high tinting strength. Such materials appear in different geological settings, with varying amounts of iron oxides or iron oxyhydroxides (Hodgskiss 2010, 2020; Rifkin 2011, 2012). The study of the collection and use of ochre during the Middle Stone Age is well documented in the archaeology of Southern Africa (see Hodgskiss 2020 for a synthesis of this study). Henshilwood and others have noted the symbolic use of ochre in the evolution of modern human behaviors (Henshilwood 2002; Henshilwood et al. 2018). Hence, many studies have been conducted to analyze ochre pieces recovered within MSA layers (e.g., Barham 2002; Bernatchez 2008; Dayet et al. 2013; d'Errico et al. 2012; Hodgskiss 2012, 2013; Moyo et al. 2016; Rifkin et al. 2016). In contrast, the use of ochre in LSA contexts is understudied, especially given the large number of rock art sites where ochre has been discovered (Fig. 1; see Online Resource 1). As synthetized by Le Quellec (2018), Southern African rock art studies have long focused on the Drakensberg paintings. Innovative ap-proaches have led to a renewal of rock painting studies in other regions, and these have highlighted the diversity of rock art traditions in Southern Africa (Challis 2012, 2016; Le Quellec 2018; Ouzman 2005). Significant works have been carried out to characterize the pictorial layers of these paintings (Bonneau et al. 2012, 2014; Hughes and Solomon 2000; Mauran et al. 2019; Prinsloo et al. 2008; Tournié et al. 2011; Van Rijssen 1990) and date them directly or indirectly (Bonneau et al. 2014, 2017; Mazel 1993; Mazel and Watchman 1997; Watchman and Mazel 2003). Others sought to identify the regional specificities of the different South-ern African rock art clusters (Challis 2012, 2016; Eastwood and Smith 2005; Smith et al. 2004). Some studies have analyzed the paintings' scenic narratives and explored the interactions between the rock arts and their environment (Breunig 2019; Breunig et al. 2018; Lenssen-Erz 2004; Holl 2017; Nankela 2015, 2017).

The discovery of ochre within LSA archaeological layers below rock paintings has often led researchers to consider that ochre was used only for rock paintings and that the discarded ochre pieces are waste materials. Therefore, these materials remain understudied (e.g., Breunig 2003; Kinahan 1990; Richter 1991; Vogelsang 1998; Vogelsang and Eichhorn 2011; Wendt 1972). As a result, only four multianalytical studies have been conducted on the ochre finds from Southern African LSA contexts (Bernatchez 2008; Hahndiek 2014; Hughes and Solomon 2000; Steele et al. 2016), despite the large number of sites where LSA ochres have been recovered. During their prelim-inary work on LSA ochres from four rock art sites in KwaZulu-Natal, Hughes and Solomon (2000) pointed to the lack of knowledge about ochre resources. Their preliminary work demonstrated that the ochres from these sites were of high diversity and might be correlat-ed to the rock art in the area. But they could not go further with their study due to the diversity of sites they studied, both chronologically $(1,290-9,180$ years BP) and geographically.

To our knowledge, only a doctoral thesis correlates ochre from LSA layers and rock paintings at Andriesgrond, Diepkloof, and De Hangen (Hahndiek 2014). This study noted that it is difficult to ascertain the relationship between the rock paintings and the ochre fragments found below them. Two noteworthy studies have been carried out by Bernatchez (2008) at Nelson Bay Cave (Western Cape, South Africa) and Steele et al. (2016) at Varshe River 003 (Western Cape, South Africa). Both are unpainted LSA-MSA sites that have delivered some ochre fragments. In her study, Bernatchez (2008) identified different groups of archae-ological ochres, pointing to the exploitation of different sources at the same time. Thanks to her diachronic approach, she also demonstrated some procurement changes during the Later Stone Age Wilton, Albany, and Robberg occupations of Nelson Bay Cave. In her conclusion, she called for the continuation of this study through provenience studies of Nelson Bay Cave ochres and of other sites in the region. This task was recently completed by Steele et al. (2016), who excavated Varshe River 003 and conducted geological surveys in the region. The authors noticed diversity in the lithology of the ochre fragments at the site. They considered that this diversity was pointing to the exploitation of numer-ous sources. For them, it could reflect either high mo-bility 
of the population or a high level of exchange activity. But the connection with other sites and the nature of their use are uncertain. Moreover, ochre provenience studies have not been carried out.

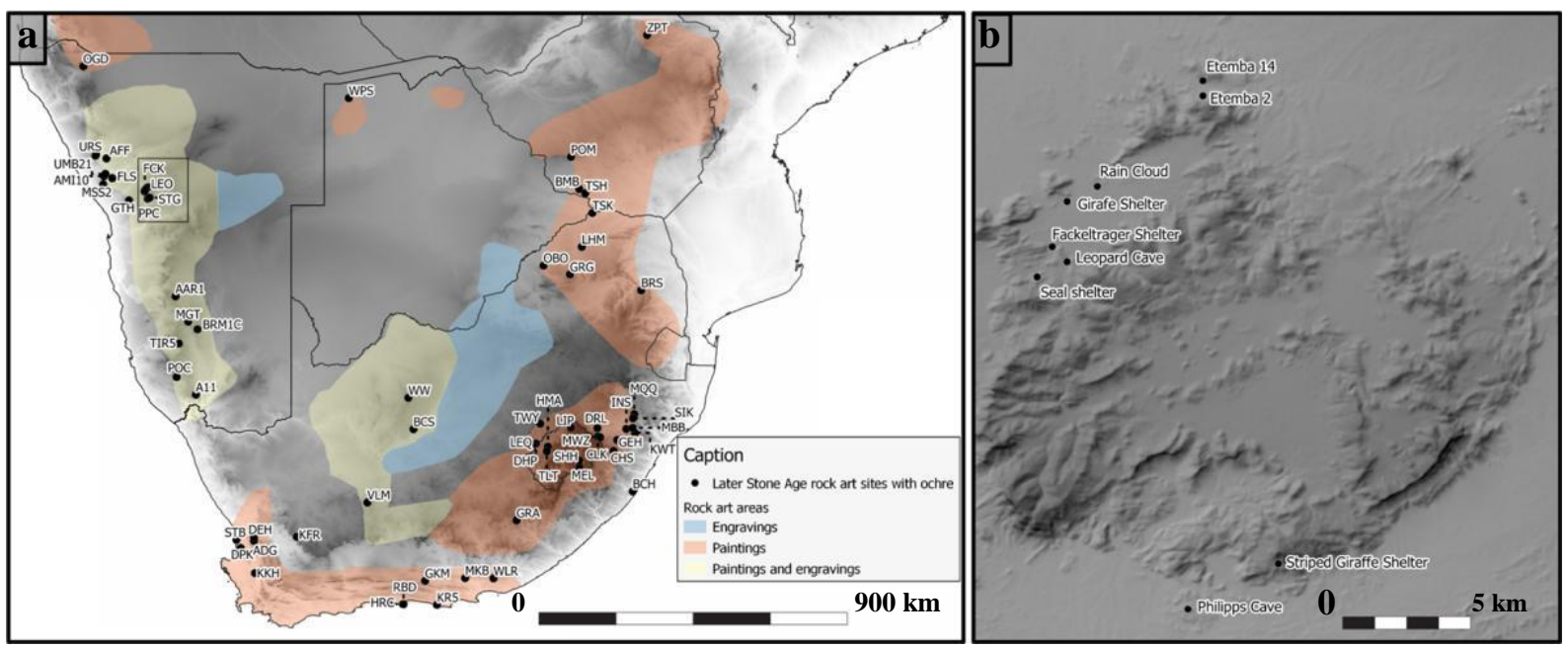

Fig. 1 Southern African rock art sites with archaeological ochre assemblage: a regional context; b Erongo Mountains (Namibia)

Archaeologists have extensively surveyed many sites in Central Namibia for several decades and recorded thousands of rock art sites in different massifs, including the Brandberg, the Erongo, and the Spitzkoppe (Breuil 1955; Breuil et al. 1960; Breunig et al. 2018; Börner 2013; Holl 2017; Hollmann and Steyn 2003; Kinahan 1990, 2000, 2010; Nankela 2017; Pager and Breunig 1989; Pager 1993, 1995, 1998, 2001, 2005, 2006; Scherz 1970; Vallverdu et al. 1979). Excavations have also been carried out to provide archaeological contexts for the various rock art sites and to identify the different phases of human occupation in the region (Breunig 2003, 2019; Breunig et al. 2018; Kinahan 1990; Pleurdeau et al. 2012; Richter 1991; Wendt 1972). These studies provide valuable insights for understanding central Namibian rock art. However, no investigation was carried out on the ochre assem-blages discovered at the different rock art sites in the region (Table 1, Fig. 1, and Online Resource 1). Nevertheless, some of these studies have discussed the sociocultural contexts of the rock art sites, thanks to the discovery of exfoliated painted flakes within archaeological layers dated to 3,000 BP at Amis 10 (Breunig 2003; Pager and Breunig 1989) and the discovery of what could be interpreted as evidence of ritual practices at Falls Rock Shelter (FLS, Brandberg; Kinahan 2018). The chronology of these Namibian rock arts rests mainly on stylistic analyses and comparison with the other Southern African rock arts (Kinahan 2000, 2010; Nankela 2017; Richter 1988, 1995, 2002; Richter and Vogelsang 2008). Despite the attempts made by Conard et al. (1988), no direct dating has so far been performed on Namibian rock art due to the scarcity of dating materials.

The Erongo Mountains, a circular volcanic and in-trusive rock complex of Jurassic to Cretaceous age (Blümel et al. 1979), located at the edge of the Namib Desert, are known to host numerous rock paintings and engravings attributed to LSA hunter-gatherers (Breuil et al. 1960; Börner 2013; Hollmann and Steyn 2003; Nankela 2017; Scherz 1970; Vallverdu et al. 1979). The rock complex is regarded as a critical area for under-standing LSA hunter-gatherers' behavior in semi-arid environments. It contains numerous archaeological rock art sites where ochre fragments have been found in LSA contexts, and in association with rock art paintings (Online Resource 1). These sites include Fackelträger (Richter 1991; Wendt 1972), Etemba 2 (Richter 1991), Etemba 14 (Richter 1991), Rain Cloud, Giraffe Shelter, and Seal Shelter (Pleurdeau, personal communication), and Leopard Cave (LC - Pleurdeau et al. 2012; Table 1, Fig. 1).

The LSA assemblages from the Erongo Mountains attest to the presence of human occupations all over the massif during the past 6,000 years. The LSA occupation levels have been divided into three technocomplexesWilton preceramic, Wilton ceramic, and post-Wilton (Richter 2002). They provided exceptional ochre-related assemblages in the form of numerous grinding and crushing stone tools with red residues on their surface, as well as hematite and "ochre stones". These artifacts raised the possibility of understanding the relationships between rock art paintings and human occupations and called for more excavations that seek to recover ochrerelated artifacts in their cultural contexts (Richter 1991; Wendt 1972). 
Table 1 List of the rock art sites in the Erongo Mountains cited in the text

\begin{tabular}{|c|c|c|c|}
\hline Site & Ochre description & $\begin{array}{l}\text { Dating of the archaeological layers } \\
\text { containing traces of pigments } \\
\text { processing }\end{array}$ & References \\
\hline Rain Cloud & $\begin{array}{l}\text { Hematite and red traces on grinding } \\
\text { stones }\end{array}$ & $2,500-2,000 \mathrm{cal} \mathrm{BP}$ & Unpublished data \\
\hline Fackelträger & $\begin{array}{l}\text { Hematite, red traces on grinding } \\
\text { stones, pestles and beads }\end{array}$ & $3,000-2,500 \mathrm{cal} \mathrm{BP}$ & $\begin{array}{l}\text { Wendt 1972; Richter } \\
1991\end{array}$ \\
\hline Leopard Cave & $\begin{array}{l}\text { Hematite, ferruginous rocks, red } \\
\text { traces on grinding stones, pestles } \\
\text { and beads }\end{array}$ & $3,000-2,000 \mathrm{cal} \mathrm{BP}$ & Pleurdeau et al. 2012 \\
\hline Etemba 2 & Lumps of pigment & Around $1,850 \pm 50 \mathrm{cal} \mathrm{BP}$ & Wendt 1972;Richter 1991 \\
\hline Etemba 14 & Lumps of pigment & Around $190 \pm 60 \mathrm{cal} \mathrm{BP}$ & Wendt 1972; Richter 1991 \\
\hline Giraffe Shelter & $\begin{array}{l}\text { Hematite and red traces on grinding } \\
\text { stones }\end{array}$ & No data available & Unpublished data \\
\hline Philipps Cave & Hematite and red « ochre » & Around $3,368 \pm 200 \mathrm{cl} \mathrm{BP}$ & Martin and Mason 1954 \\
\hline Seal Shelter & $\begin{array}{l}\text { Hematite, red traces on grinding } \\
\text { stones, pestles and beads }\end{array}$ & No data available & Unpublished data \\
\hline Striped Giraffe & Small red, brown and yellow pieces & Before $2,640 \pm 100$ cal BP & $\begin{array}{l}\text { Sandelowksy \& Viereck } \\
1969\end{array}$ \\
\hline
\end{tabular}

The excavations carried out since 2014 at the rock art shelter of Leopard Cave led to the discovery of numerous artifacts that indicate intensive use of ochre. These diverse remains document a unique archaeological context within a painted shelter attributed to LSA hunter-gatherers in Southern Africa. They provide crucial insights into the cultural-economical behaviors of these communities and the origins of rock paintings in the region. This article presents the artifacts relating to ochre processing in Leopard Cave and makes some inferences about the sociocultural behaviors of the LSA populations who occupied the cave. We will also show the existence of intense ochre processing activity at the site.

\section{Leopard Cave}

Leopard Cave is a painted rock shelter located within a Cretaceous granitic spur. It lies in the Omaruru region in the northwestern part of the Erongo Mountains (Fig. 1b). Located on Omandumba West Farm, the shelter stands at an altitude of 1,256 m above sea level and $1.7 \mathrm{~km}$ south of the archaeological site of Fackelträger excavated by Wendt in the 1960s (Richter 1991; Wendt 1972). Leopard Cave opens towards the south, facing the hills of the Erongo Mountains. The site consists of a small rock shelter of approximately $60 \mathrm{~m}^{2}$ (about $8 \mathrm{~m} \mathrm{long}$ ), mostly covered by the overhang of a granite boulder (Fig. 2a-c).

Leopard Cave was discovered in 2006 during a pedestrian survey. The initial coring highlighted the archaeological potential of the site, and excavations took place over several years (2007-2009, 2011-2012, and 2014-2018). Currently, $16 \mathrm{~m}^{3}$ of sediments have been excavated from nine squares (M6-7, N6-8, O7-8, and P7-8; Fig. 2d). The excavation revealed a 1.8-m-deep stratigraphic sequence documenting a succession of human occupations. The archaeological assemblage is comprised of quartz and basalt lithic artifacts, faunal remains, bone points, link shafts and needles, pendants, and ostrich eggshells (OES) beads, among others. All artifacts point to an LSA hunter-gatherers tradition that was based on opportunistic stone tool production (Pleurdeau et al. 2012). The archaeological assemblage also includes ochre fragments $(\mathrm{n}=366)$, grinding and crushing stone tools (active and passive, $\mathrm{n}=15$ ), and ornamental artifacts with red pigment traces on their surface (OES beads, $\mathrm{n}=61$; bone pendants, $\mathrm{n}=1$; bone bead, $\mathrm{n}=1$ ). Following the discovery of numerous ochres and tools bearing pigment traces in 2014, the excavation of Leopard Cave was expanded towards the eastern wall of the shelter (squares O7-8, Fig. 2b) to investigate the possible connection between the archaeological assemblage and the rock art. In 2015, the excavation revealed red traces on the wall. 
The sequence was subdivided into three stratigraphic complexes. There is evidence of some localized burrows cutting through the stratigraphic profiles. The archaeological materials found within these burrows are excluded in the present study. The upper complex I spans between - 120 and - $250 \mathrm{~cm}$ (Fig. 2d). Granitic "arena," silt, and an ash mixture of anthropic origin with abundant vegetable remains and charcoals are the main com-ponents of the nine subhorizontal layers of this complex, labeled from "a" to "j" (Fig. 2d and Table 2). The texture of the upper complex I derived from the powdered silts resulting from the breakdown of the granite. The presence of ash/charcoal and a large number of artifacts recovered from this stratigraphic complex demonstrate the existence of intense anthropic activities.

Complex II, between -250 and $-280 \mathrm{~cm}$, constitutes deliquescent granite that probably corresponds to a phase of collapse. The few artifacts discovered within these layers appear to be downward infiltration and infilling between the collapsed granitic blocks. Finally, complex III, starting from $-280 \mathrm{~cm}$, is made of an indurated arenaceous matrix, deprived of any ash or organic material. The substratum has not been reached, and a test-core indicates that at least $20 \mathrm{~cm}$ of artifact-bearing sediment remains unexcavated.

\section{Chronology}

The chronology of the Leopard Cave shelter strati-graphic sequence has been determined, based on 18 radiocarbon dates from charcoal samples. Table 2 lists all of these radiocarbon dates and provides information about their location at the site. Radio-carbon ages were calibrated using the OxCal 4.3 software (Bronk Ramsey 2009) with the SHCal13 calibration curve (Hogg et al. 2013). The infilling was deposited between 13,600 \pm 230 cal. BP (com-plex III, layer m) and 2,000 $\pm 150 \mathrm{cal}$. BP (complex I, layers $\mathrm{c}-\mathrm{e}$ ). The chronology tends to point to the existence of three significant periods of human occupations in complex I: between 5,700 and 3,200 cal BP (layer g), around 2,300-2,500 cal BP (layer f), and after 2,100 cal BP (layers c-e). Three dates obtained for samples SacA51308, SacA51309, and SacA51311 appear to be out of the chronological range of the site occupation. They are likely localized postdepositional events and resulted from intrusions from the upper layers.

Samples CA-DAT_AD36A and CA-DAT_AD36C provided important chronological data. The sample was obtained from a concretion covering the east wall of the shelter, a terminus ante quem for the covering of the wall by sediments. Archaeological layers located at the same levels, but deposited before the formation of this concretion, are dated to 3,200 cal BP. The C14 dates from CA-DAT_AD36A and CA-DAT_AD36C suggest $2,200 \mathrm{cal} \mathrm{BP}$ as the terminus ante quem for the covering of the wall by sediments.

\section{Methods}

\section{Rock Painting Documentation}

To study the parietal paintings and red traces on the walls of Leopard Cave, we photographically documented the walls and roof of the shelter with a Nikon D3300 with $105 \mathrm{~mm}$ focal distance. These pictures were then treated with Dstretch ${ }^{\circledR}$ (Harman 2008), according to the method published by Le Quellec et al. (2013). Descriptions and analysis of these paintings can be found in Nankela (2017) and Mauran et al. (2019).

\section{Ochre Description}

Archaeological pieces were first observed visually be-fore any treatment to evaluate their fragility and the possibility of washing them. The washing was per-formed with deionized water and ultra-sonication for 3 min for the hardest pieces. Only deionized water was used for the weaker ones, and a few were not cleaned at all in order not to destroy them. Once cleaned, the objects were observed with a binocular microscope (LEICA), and photos were taken with a Nikon D3300 with $105 \mathrm{~mm}$ focal distance. The description of the samples is presented 


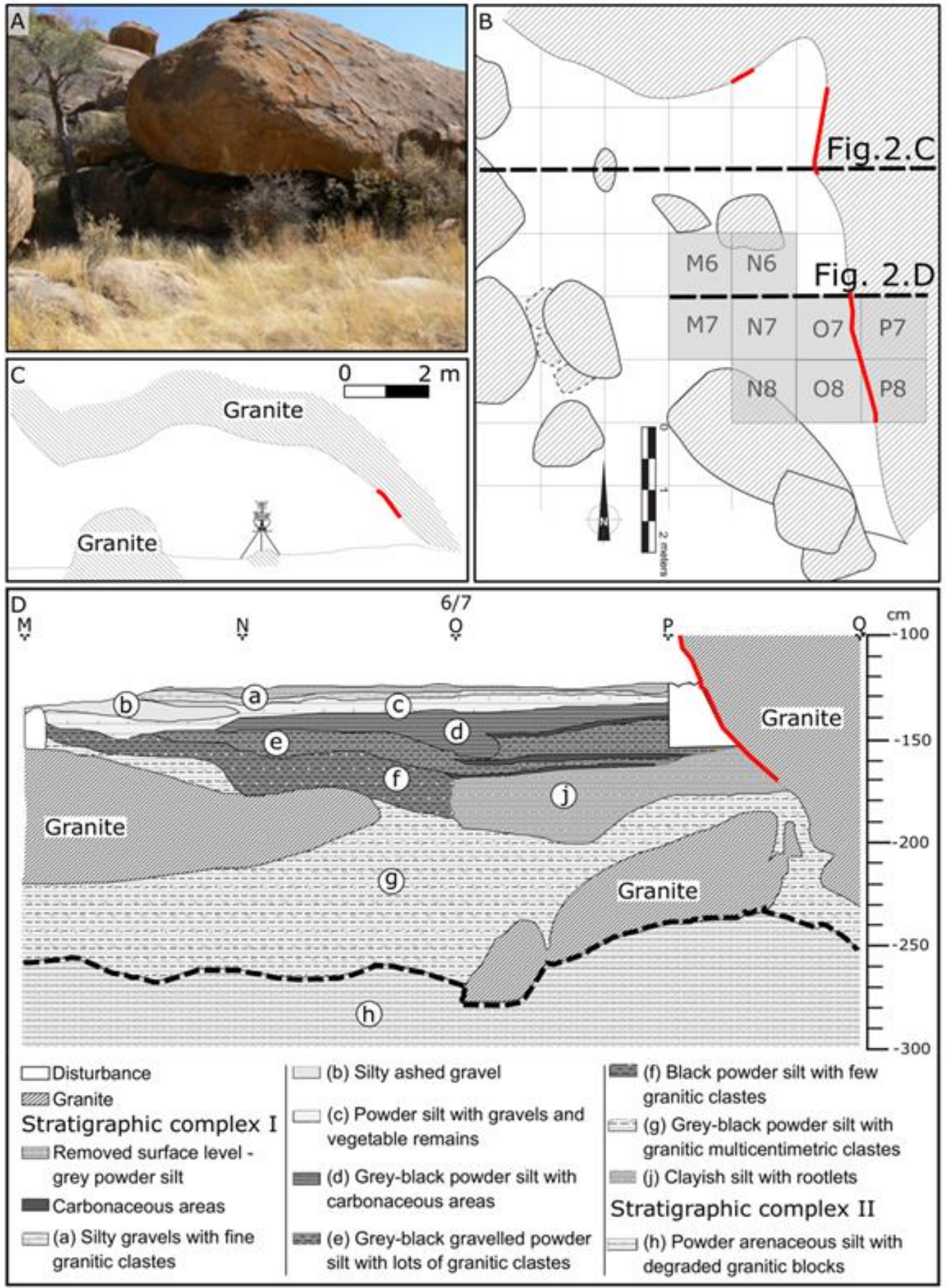

Fig. 2

Leopard Cave (a), showing (b) excavated squares within the shelter-red lines indicate the location of the paintings in the shelter; (c) shelter profile; and (d) stratigraphic sequence of cut $6 / 7$

'in Online Resource 2, based on the following characteristics (see Dayet 2012; Hodgskiss 2010; Pradeau 2015; Salomon 2009):

\& Block weight: measured to the milligram

\& Block dimensions: measured with a caliper to the millimeter

\& Main block hue: observed on natural surfaces

$\&$ Powder hue: observed on microsample 
\& Tinting strength: estimated during manipulation of the block—gentle (not tinting the skin at seizing) to strong (tinting the skin at seizing) handling

\& Block cohesion: estimated during manipulation of the block - gentle (the block breaks off at seizing) to strong (the block does not present any structural weakness) handling

\& Block hardness: estimated during manipulation of the block, ranging between gentle (a copper coin can scratch the block) and strong (the block can scratch a copper coin) handling

\& Matrix homogeneity: estimated with the observation of a fresh break on the block, between homogenous and heterogeneous

\& Matrix structure: described from a fresh break on the block

\& Porosity of the block: estimated from the observa-tion of the block between low (no pore visible with abinocular microscope) to high (presence of macropores visible at bare eyes)

\& Granulometry of the block: estimated from the ob-servation of the block and described as being be-tween fine and coarse grain size

\& Block luster: description of the luster (metallic, submetallic, greasy, or no luster)

\& Presence of inclusion: inclusion description from binocular microscope observations of the block

\& Magnetization: estimated from a magnet test be-tween low (no reaction to a magnet) to high (strong reaction to a magnet)

These observations and descriptions permitted us to assess the diversity of the ochre found at Leopard Cave.

Table 2 Radiocarbon dates at Leopard Cave

\begin{tabular}{|c|c|c|c|c|c|c|c|c|}
\hline Lab ID & Laboratory & $\begin{array}{l}\text { Stratigraphic } \\
\text { complex }\end{array}$ & Square & Layer & $\begin{array}{l}\text { Depth } \\
(\mathrm{cm})\end{array}$ & Nature & $\begin{array}{l}\text { Conventional } \\
\text { radiocarbon age, BP }\end{array}$ & $\begin{array}{l}\text { Age cal BP (2 } \\
\text { sigma) }\end{array}$ \\
\hline SacA3262 & LMC14 & I & N6 & $\mathrm{c}$ & 143.5 & Charcoal & $2,150 \pm 30$ & $2,100 \pm 100$ \\
\hline Beta-270163 & Beta analytic & I & N7 & e & 157.5 & Tooth & $2,190 \pm 40$ & $2,100 \pm 100$ \\
\hline SacA34261 & LMC14 & I & M6 & $\mathrm{i}$ & 159 & Charcoal & $2,565 \pm 30$ & $2,600 \pm 150$ \\
\hline Beta-270,164 & Beta analytic & I & N7 & $\mathrm{f}$ & 163 & Tooth & $2,270 \pm 40$ & $2,200 \pm 100$ \\
\hline Beta-236,963 & Beta analytic & I & N7 & $\mathrm{f}$ & $166-176$ & Charcoal & $2,430 \pm 50$ & $2,500 \pm 200$ \\
\hline CA_DAT_AD63C & CARAA & I4 & P8 & $\begin{array}{l}\text { In concretion } \\
\text { over the wall }\end{array}$ & 168 & Charcoal & $2,105 \pm 45$ & $2,100 \pm 100$ \\
\hline UBA-30945 & 14OCHRONO & I & P7 & $\mathrm{f}$ & 175.5 & Charcoal & $2,209 \pm 33$ & $2,200 \pm 150$ \\
\hline UBA-30946 & 14OCHRONO & I & P7 & $\mathrm{g}$ & 192 & Charcoal & $3,064 \pm 32$ & $3,200 \pm 150$ \\
\hline Beta-236,964 & Beta analytic & I & N7 & $\mathrm{g}$ & $196-206$ & Charcoal & $3,250 \pm 40$ & $3,500 \pm 100$ \\
\hline CA_DAT_AD63A & CARAA & I & P8 & $\begin{array}{l}\text { In concretion } \\
\text { over the wall }\end{array}$ & 203 & Charcoal & $2,267 \pm 45$ & $2,200 \pm 150$ \\
\hline SacA51308 & LMC14 & I & O8 & Displaced (f) & 224 & Charcoal & $2,105 \pm 30$ & $2,000 \pm 150$ \\
\hline SacA42295 & LMC14 & I & N7 & $\mathrm{g}$ & 263.5 & Charcoal & $3,465 \pm 30$ & $3,700 \pm 150$ \\
\hline CA_DAT_AD63B & CARAA & II & P8 & g & $240-250$ & Charcoal & $4,508 \pm 45$ & $5,100 \pm 200$ \\
\hline SacA42299 & LMC14 & II & N7 & g & 271.5 & Charcoal & $3,000 \pm 30$ & $3,100 \pm 150$ \\
\hline SacA51309 & LMC14 & II & N7 & Displaced (f) & 281 & Charcoal & $2,330 \pm 30$ & $2,300 \pm 100$ \\
\hline SacA51311 & LMC14 & II & O8 & Displaced (f) & 285 & Charcoal & $2,345 \pm 30$ & $2,300 \pm 100$ \\
\hline SacA53511 & LMC14 & II & $\mathrm{O} 7$ & $\mathrm{~h}$ & 290 & Charcoal & $49,45 \pm 30$ & $5,700 \pm 100$ \\
\hline SacA51310 & LMC14 & III & $\mathrm{O} 7$ & $\mathrm{~m}$ & 300 & Charcoal & $13,040 \pm 70$ & $13,600 \pm 230$ \\
\hline
\end{tabular}

\section{Anthropic Modification of Ochre Fragments}

The experimental studies performed on ochre allowed inferences to be made on the existence and nature of anthropogenic modifications (Dayet 2012; Hodgskiss 2010; Rifkin 2012; Rosso et al. 2017; Salomon 2009). 
'After visual examination, we classified the ochre fragments from Leopard Cave into two groups: unmodified and' possibly modified. The modifications were considered according to the presence of striations, facets, fracturing edges, polished surfaces, and flake scars. According to the previous works of Hodgskiss (2010) and Rifkin (2012), we divided the potential anthropic modifications into two main groups: fragmentation and grinding. However, as no experimental study has been carried out on pure iron oxides or single fragmentation scars, we considered all the fragmentation scars as potential traces of anthropic modifications. These observations were coupled with the ones made on grinding and crushing tools, all stone items that have been intentionally modified through the pounding and grinding of other materials (Dubreuil and Savage 2014; Ebeling and Rowan 2004; Hayes et al. 2017). The two anthropic modifications are described below.

1. Fragmentation aims at decreasing the volume of the blocks. It can be achieved through various actions: knapping, pounding, or crushing. These actions leave distinct marks on the blocks. Knapping, pounding, and crushing are often continuous actions to reduce the initial blocks into small shards and pigment powder (Dayet 2012; Salomon 2009). The small shards that were not reduced to powder bear traces of "fresh" sharp edge and "fresh" fracturing surfaces. Traces on the tools used to crush and grind are more evident as they correspond to percussion pits, and the saddle shape of the grinding slabs bear red residues on their surface. Knapping performed on ochre leaves scar traces, although these are sometimes hard to observe (Henshilwood et al. 2009; Salomon 2009).

2. Grinding aims at shaping, altering the surface of the blocks, and producing pigment powder (Henshilwood et al. 2009; Hodgskiss 2010; Rifkin 2012; Salomon 2009). Grinding use-wear is more evident on ochre fragments than traces of fragmentation. It consists of facets and multiple groups of parallel striations on the surface of both the ochre piece and the grindstone on which the blocks were rubbed. On the tools, ochre grinding use-wear patterns mainly consist of red tint, ochre grain residues, and leveling or smoothing of the microrelief on the active surface of the tool (Hayes et al. 2017). Other possible anthropic modifications consist of ochre thermic treatment (Dayet 2012; Pomiès et al. 1999; Salomon et al. 2014). Only the archaeological context allows the differentiation of intentional treatment from accidental or postdepositional heating (Salomon et al. 2012, 2015; Wadley 2009). The large charcoal beds and the extensive number of heat-exploded lithics found at Leopard Cave prevent us from considering the potential thermic treatment intended for the ochre fragments at the site.

\section{Description of Ochre Residues on Artifacts}

The residues on artifacts were described according to the methodology proposed by Pradeau (2015). All tools and ornaments were first observed with the naked eye to spot the presence of red residues and determine the part of the artifact on which they are present. All artifacts with residues on one of their surfaces were documented through various photographs with a Nikon D3300 with $105 \mathrm{~mm}$ focal distance. To enhance the visibility of the red residues present on the tools, the pictures were treated with Dstretch ${ }^{\circledR}$ (Harman 2008). All pictures were treated with the YRD filter. We then documented the presence of pits, smoothed edges, striations, and their relations with the red residues found on these artifacts.

\section{Results}

\section{The Parietal Pigment Residues: Red Representations and Their Weathering}

Eastern and northern walls of Leopard Cave bear red parietal representations or pigment traces (Figs. 2b and 3). Differential erosion and weathering caused large granitic slabs to detach from their bedrock. Paintings seem to have been performed after the collapse of these large granitic slabs. Today, these representations are all located 
in the lowest parts of the walls. But given the recent sedimentation experienced in the shelter, the former surface levels must have been much lower, placing the paintings at about the eye level during the LSA occupations. Twelve figures and one area of diffuse red flat tint have been recorded and described (Nankela 2017). Among the 12 motifs identified, four are anthropomorphic, while four are zoomorphic (a headless giraffe, an antelope, a duiker, and a giraffe head). Another four figures are classified as indeterminable. All paintings exhibit fine-line appearance, a characteristic of the rock paintings in the Erongo region (for example, see the back legs of the antelope displayed in Fig. 3b; Nankela 2017; Richter 1991). Only red monochromes were observed at this site. Most of the paintings are in a poor state of conservation, as a result of natural weathering and anthropogenic activities resulting in dust coating. Substantial black residues covering the ceiling prevent us from assessing the possibility for the presence of paintings in this part of the cavity. Only the headless giraffe is still clearly visible (Fig. 3a), while all other paintings vanished under white crusts, such as the back legs of the antelope (Fig. 3b), or as the result of both water and sandy wind erosions - the headless giraffe (Fig. 3c).

The 2015 excavation of the subsquares lying next to the eastern wall (squares P7-P8) allowed us to clear the wall from the sediment covering it, and red traces were observed on the wall (Fig. $3 \mathrm{f}-\mathrm{h}$ ) between levels at $\mathrm{z}=-$ $162 \mathrm{~cm}$ (27 cm below the surface) and $\mathrm{z}=-189 \mathrm{~cm}$ (54 cm below the surface) (Fig. 3f). These red traces could have resulted from the natural red tint of the granite, the presence of vanished red painting, or the leaking of pigments from wall sections above this area. The in situ pXRF analyses confirmed that the origin of the red tint was from the anthropogenic presence of iron pigment (Mauran et al. 2019).

\section{Ochre Fragments and Pigment Traces on the Archaeological Materia}

Ochre fragments ( $\mathrm{n}=366$ ), tools (grinding slabs and handstones, $\mathrm{n}=15)$, and ornaments (OES, bone beads, and bone pendant) bearing traces of pigments were discovered in stratigraphic complex I at the bottom of the painted wall (squares O/P; Fig. 2b). The presence of a grinding slab (T-LC-01) and a handstone (T-LC-07) — both bearing traces of use and an ochre piece with an abraded surface (LC-030, Fig. 4a) - are convincing ev-idence of the mechanical transformation of ochre at the site.

\section{Nature of the Ochre Fragments}

The blocks of raw ochre that we studied were recovered from the 2014-2018 excavations. They are 366 pieces, representing a total mass of about $1.1 \mathrm{~kg}$. They could be divided into two main macroscopic groups: black metallic iron oxides and red ferruginous rocks (Table 3 and Fig. 5). The first group corresponds to wellcrystallized iron oxides and includes 171 elements for a total weight of $0.7 \mathrm{~kg}$, representing $47 \%$ of the collection in the number of samples and $68 \%$ in mass. The pieces present a gray to black nodule aspect with a submetallic to metallic brilliance. They have the attributes of high cohesion and hardness with a homogenous matrix and a massive structure (Fig. 5). Their external surface is smooth without any sharp edges but with a metallic

glow, as exemplified in samples LC-047, LC-049, LC-189, and LC-301 in Fig. 5. Within the matrix, various inclusions are present. The predominant ones correspond to millimetric to centimetric quartz inclusions.

The second group is made up of different ferruginous rocks and comprises 195 specimens (53\% of the total number) and totaling $0.4 \mathrm{~kg}$ ( $36 \%$ in mass). The characteristics of these pieces are the following: red to yellow hues, no brilliance, medium to low cohesion and hardness, and heterogeneous matrix (Fig. 5). How-ever, this ferruginous rock group also comprises pieces of various textures ranging from granular (LC-255, LC-283, LC248, LC-030) to well-stratified (LC-298) or heterogeneous (Fig. 5). Therefore, this group comprises ferruginous sandstones $(n=65)$, banded ironstone $(n=59)$, ferruginous mudstones $(n=26)$, and other ferruginous altered rocks $(n=45)$. Since we did not observe any difference in their spatial distribution or potential treatment, we decided to gather them into a single group of ferruginous rocks. 

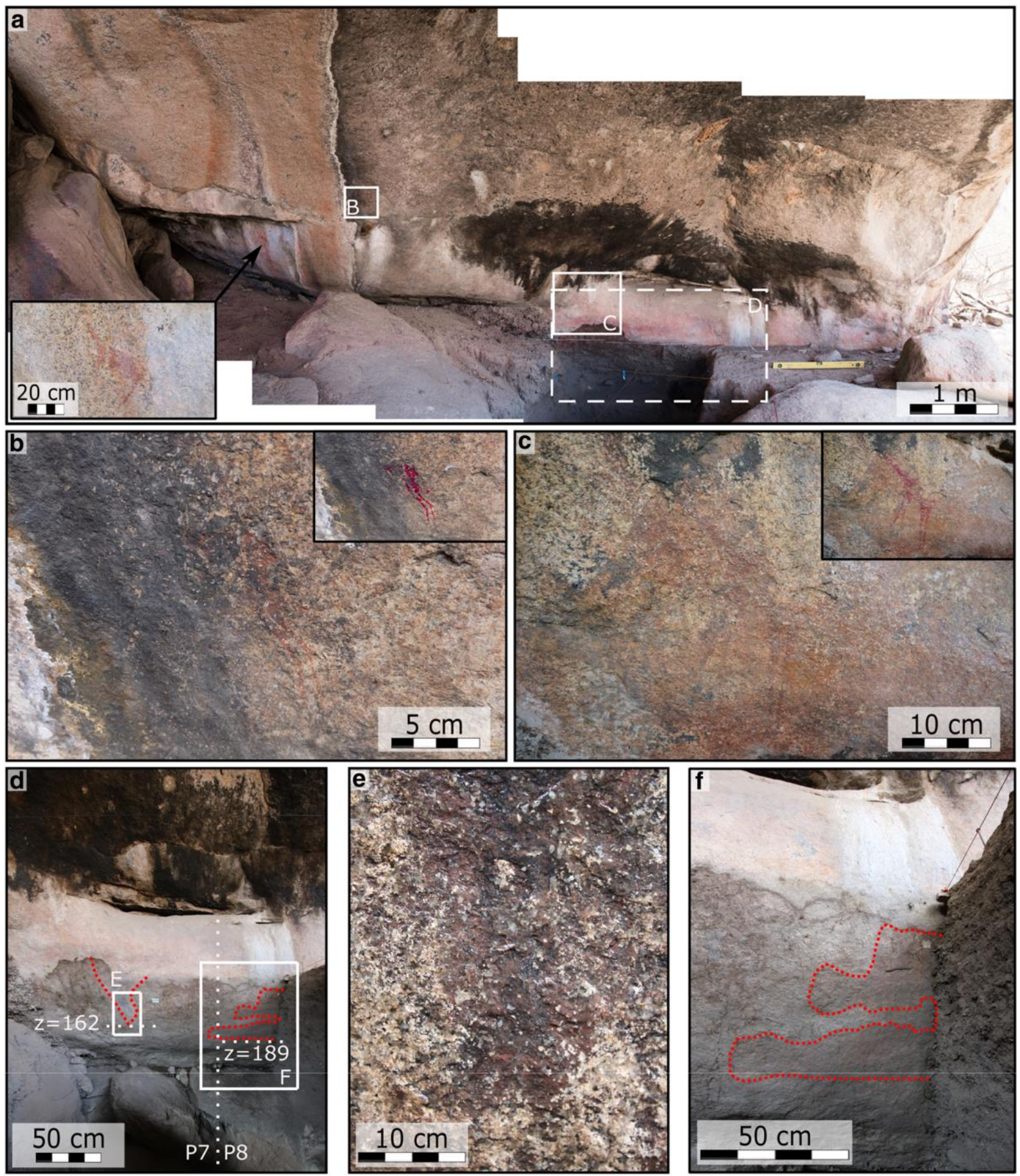

Fig. 3 Red pigment traces and paintings on the eastern wall of Leopard Cave 

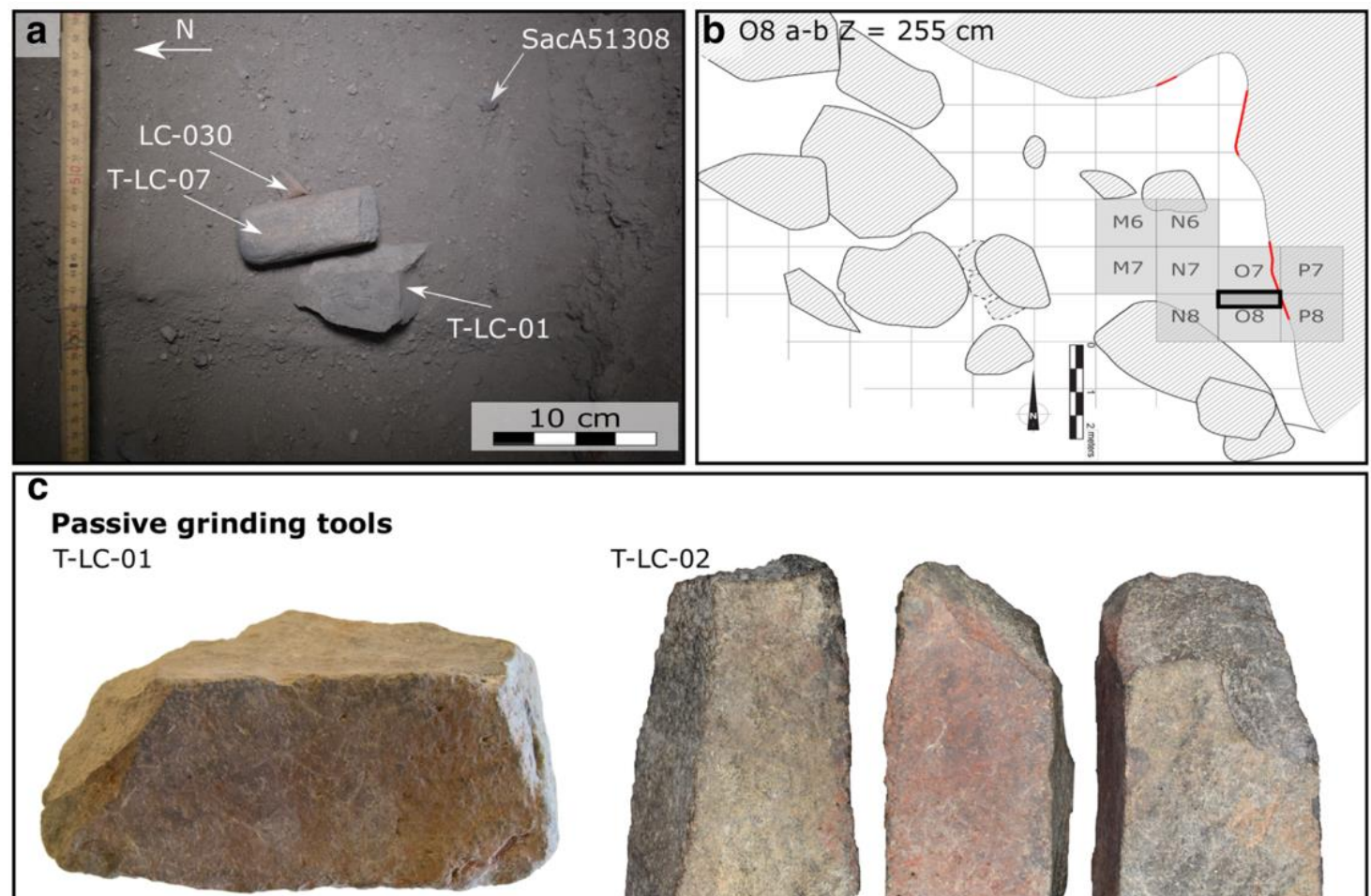

T-LC-03
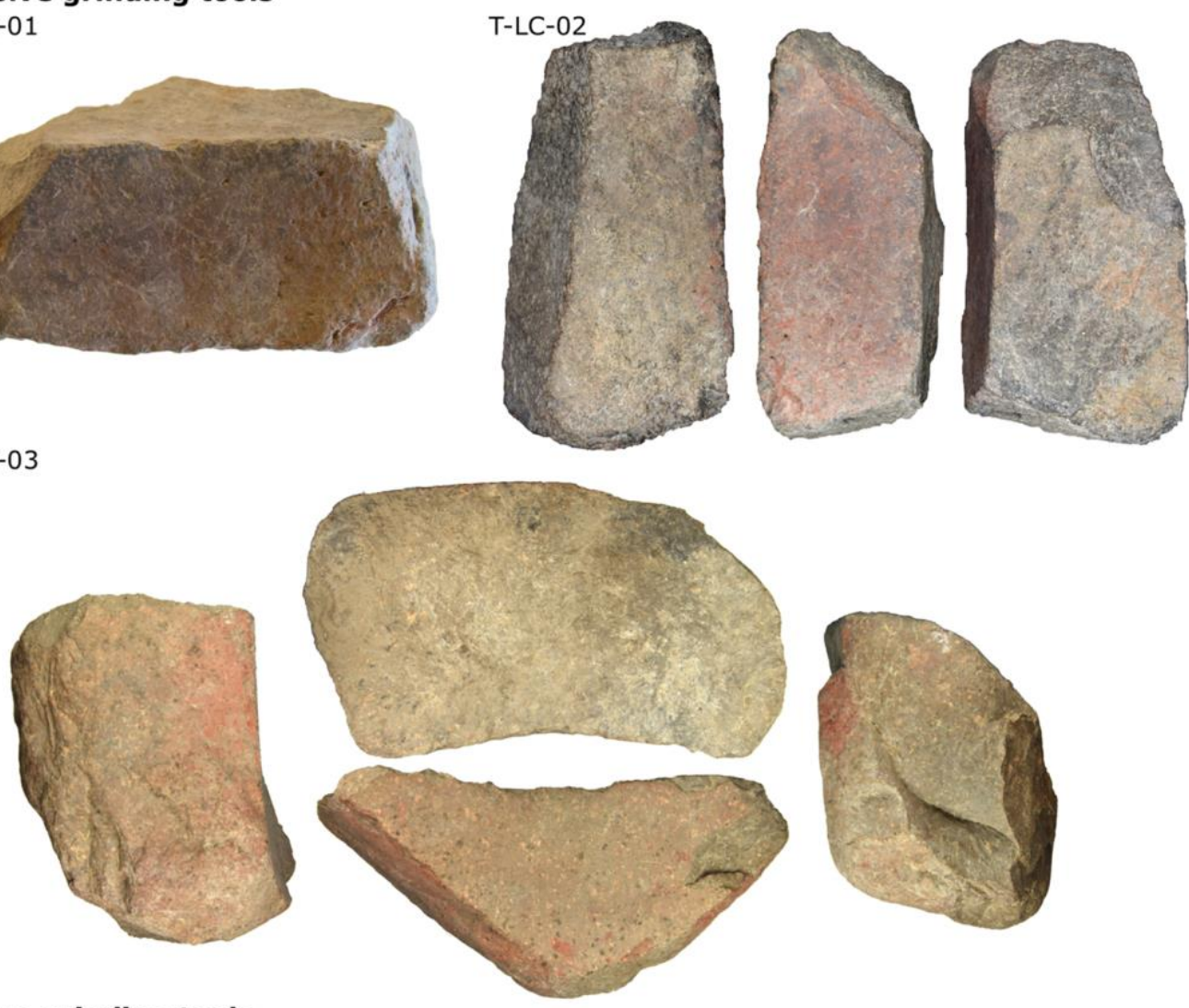

\section{Active grinding tools}
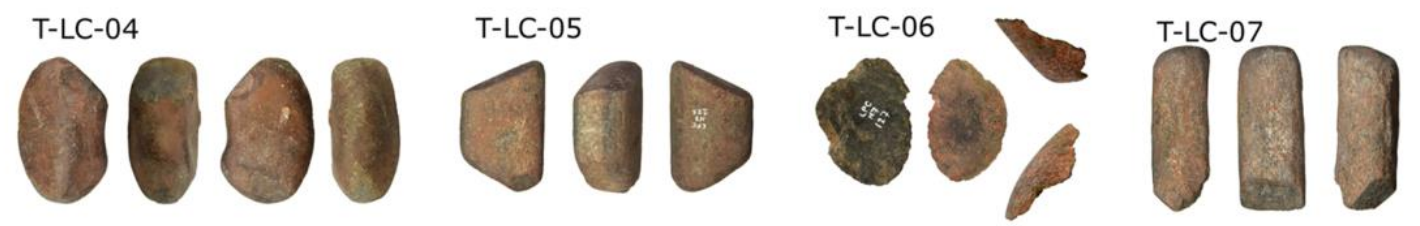

$1 \mathrm{~cm}$

Fig. 4 Grinding and crushing tools in relation with abraded ochre 


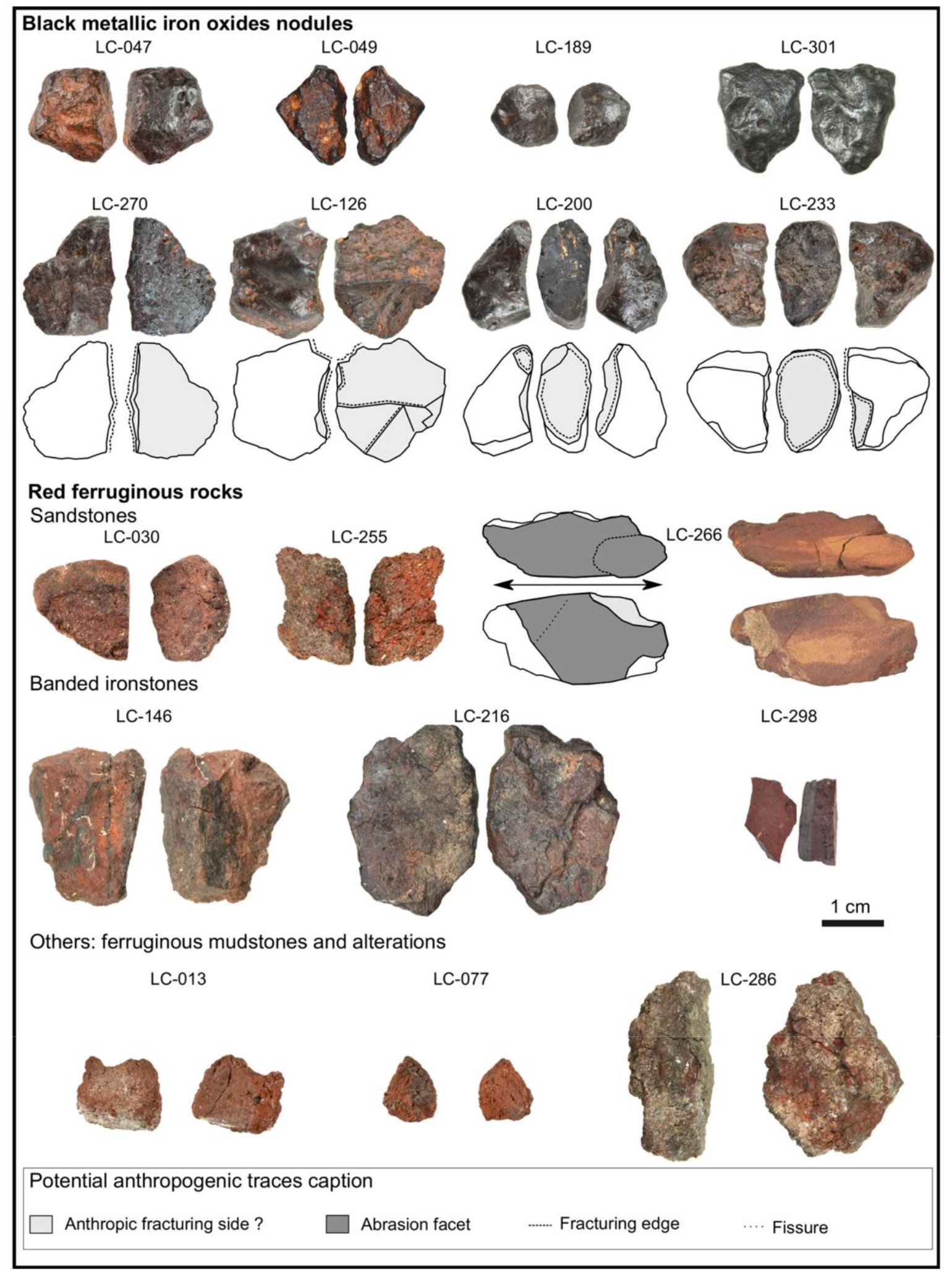

Fig. 5 Selection of ochre fragments with and without potential anthropic transformations, Leopard Cave 
Potential Anthropic Modifications of the Ochre Fragments

At Leopard Cave, 63\% of the iron oxides blocks $(n=109)$ exhibit potential marks of anthropogenic fragmentation in the form of fracturing surfaces and flake scars. Fracturing surfaces are the most prominent marks and correspond to net breaks of the pieces, such as those exemplified in Fig. 5 for LC-126, LC-200, LC233, and LC-270. Flake scars were also identified through the presence of impact points (LC-200 and LC-270 on Fig. 5). The anthropic origin of these potential fragmentation traces is reinforced by the discovery of numerous small sherds of ochre (less than $1 \mathrm{~mm}$ ), close to the blocks with those scars.

Among the ferruginous rocks, only three pieces out of 195 have striated facets (LC-030, LC-265, and LC266; Fig. 5). While LC-030 exhibits only one facet of abrasion (Fig. 5), LC-265 and LC-266 exhibit several sides that bear four and two facets of abrasions with unidirectional microstriations (Fig. 5). As these flat surfaces do not exhibit sharp grooves or extremely pronounced microstriations, they are consistent with the grinding procedure of ochre, as published by Hodgskiss (2010). Other possible use-traces consisted of fragmentation marks on numerous pieces $(n=160)$, as exemplified by LC-298 (Fig. 5).

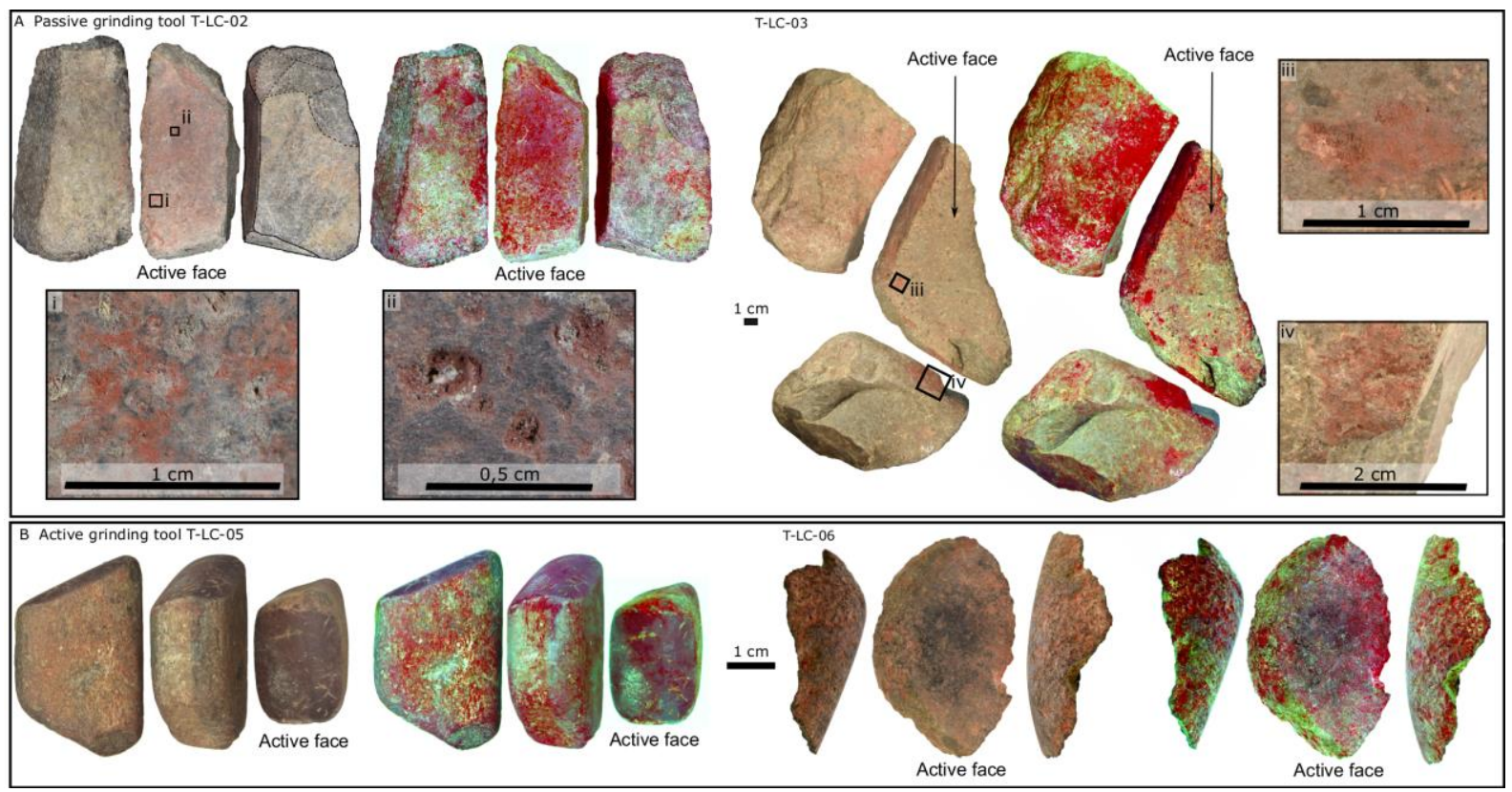

Fig. 6 Distribution and selection of red residues found on the crushing and grinding tools: natural light photos on the left and yrd Dstretch® (Harman 2008) treatments on the right

\section{Ochre Residues on Stone Tools}

Crushing and grinding tools of Leopard Cave were divided into two groups, according to the morphological classification system of Wright (1992): (1) grinding slabs (passive tools, $\mathrm{n}=6$ ) and (2) handstones (active tools, $\mathrm{n}=9$ ). Figures 4 and 6 present some of these active and passive tools. Grinding slabs are the largest tools of the Leopard Cave assemblage, measuring at least $20 \mathrm{~cm}$ long. All six grinding slabs with red residues have an active face identifiable by their smoothed microrelief and flattened aspect (e.g., T-LC-01 and T-LC-02; Figs. 4 and 6) and their saddle shape (e.g., T-LC-03; Figs. 4 and 6). They are made either from granite $(n=4)$ or basalt $(n=2)$, both readily available in the vicinity of Leopard Cave. Five of the slabs appear intact (e.g., T-LC-01 and T-LC02), while one is broken on its active surface (T-LC-03). One of the basaltic grinding slabs, T-LC-02, has been shaped on one of its pas-sive surfaces by knapping (Fig. 6a). High concentrations of red residues are found on these grinding slabs, suggesting their use to produce pigment pow-der, either by grinding or by fragmentation. 
The grinding slabs can be divided into two groups: the grinding slabs with a red tint on their active surfaces and the ones solely presenting red residues on the edges of their active surfaces.

Within the first group of grinding slabs $(n=4)$, the active surface presents a clear to diffuse red tint, and red ochre grains are visible macroscopically in the smoothed asperities of the granite and basalt slabs (Figs. 4 and 6). The presence of a red-tinted smoothed active surface, bearing grains of ochre in its asperities, is characteristic of ochre processing by grinding (Ebeling and Rowan 2004, 2004; Hayes et al. 2017). As for the second group ( $\mathrm{n}=$ $2)$, the smoothed active surface did not present any clear red tint, and red residues could only be spotted at the edges of this surface (Figs. 4 and 6). The red residues present on these artifacts might result from incidental contact with ochre pieces or ochred surfaces such as human skin or animal hide. Unfortunately, no other material was identified on the active surface, preventing us from determining the use of these stone tools.

Handstones are smaller tools, measuring around $10 \mathrm{~cm}$ long and all made of basalt. All these nine active tools with red residues present a single convex smoothed side with some pitting marks, corresponding to the active surface of the tools (Figs. 4 and 6b). Although all have some red residues on at least one of their lateral passive surfaces, only a few (T-LC-05, T-LC-06, T-LC-08) exhibited red tint or red ochre residues within the smoothed pits and microstriations on their active surface. These wear traces demonstrate the use of some of the tools to process ochre. Handstone T-LC-06 is broken but is still identifiable, thanks to the presence of an active surface covered by red residues and percussion pits. Its breakage might be related to the intensive crushing of hard materials such as iron oxides. The absence of residues on the active surfaces of some of the handstones could be due to the reuse of these tools to grind other materials, such as plants, or due to low adhesion of the ochre on the surface. The residues found only on the lateral faces could be the result of contact with an ochre-stained tool, an ochred artifact, or human skin. The modified ochre pieces, grinding tools bearing red pigment traces, a modified ochre piece, and the crushing and grinding tools with red residues over their active surface (4 grinding slabs and 4 handstones) all serve as evidence of the on-site mechanical transformation of ochre to produce pigment powder.

\section{Ochre Residues on Ornaments}

The artifacts with red residues on their surfaces are not only restricted to crushing and grinding tools at Leopard Cave but also include ornamental pieces, especially beads and pendants $(n=63)$. Schists, ostrich eggshells, bone shafts, and bone ornaments were found at Leopard Cave (Pleurdeau et al. 2012), but red residues are solely observed on ostrich eggshell (OES) beads $(n=61)$, one bone bead, and one bone pendant. The OES beads diameter lies between 3 and $7 \mathrm{~mm}$, and there are two categories of these based on the color: white to cream, and gray to black (Fig. 7). Among the 61 OES beads with red residues, the first group, comprising 57 pieces, is the most prominent. Only a few of them have small areas covered by thick layers of red residues $(\mathrm{n}=12)$. These areas are located on the lateral side (OES-LC-002, Fig. 7), in the central perforation (OES-LC-313, Fig. 7), and on inner and outer sides (OES-LC-305, OES-LC-313, OES-LC-313, Fig. 7) of the beads. On a few beads (e.g., OES-LC-305), specific use-wear patterns could be identified ( $\mathrm{Si}$ Ammour 2016). These consist of light depressions filled with red residues on both sides.

There is also an ornate bird bone tube bead measur-ing $5 \mathrm{~cm}$ long and $0.5 \mathrm{~cm}$ in diameter with 15 notches of ca. $1 \mathrm{~mm}$ deep (Fig. 7). These 15 notches present similar profiles and manufacturing techniques. They most probably were made with the same tool during a single episode. It is similar to the bone tube beads discovered at other Namibian archaeological sites (Vogelsang and Eichorn 2011). Unfortunately, the animal species to which this bone belongs could not be identified, as it is only a fragment of diaphysis with no other diagnostic features. Eight other undecorated bird bone fragments were found in the same layer, again too fragmented to be assigned to one taxon. A few red residues are still trapped within the notches. These red residues consist of packs of granular red clay, mixed with micrometric angular hematite particles. Tiny red unidirectional striations can be 
seen on these bone fragments. These tiny striations are not deep and represent hematite particles barely visible with an optical microscope; they could potentially be the result of bone polishing with some ochre.

The red residues found on the beads and pendant could be the result of the coloring of the beads or taphonomic processes. But as for most of the beads, the red residues are sporadic. Therefore, it is more likely that they resulted from indirect coloration due to contact with a colored surface, such as a colored string, cloth, or body. That is, the red residues on the beads could have derived from the ochre used to paint body or clothes, both possibly connected to identity markers (Rigaud et al. 2014; Vanhaeren and d'Errico 2003, 2005; Vanhaeren et al. 2006).

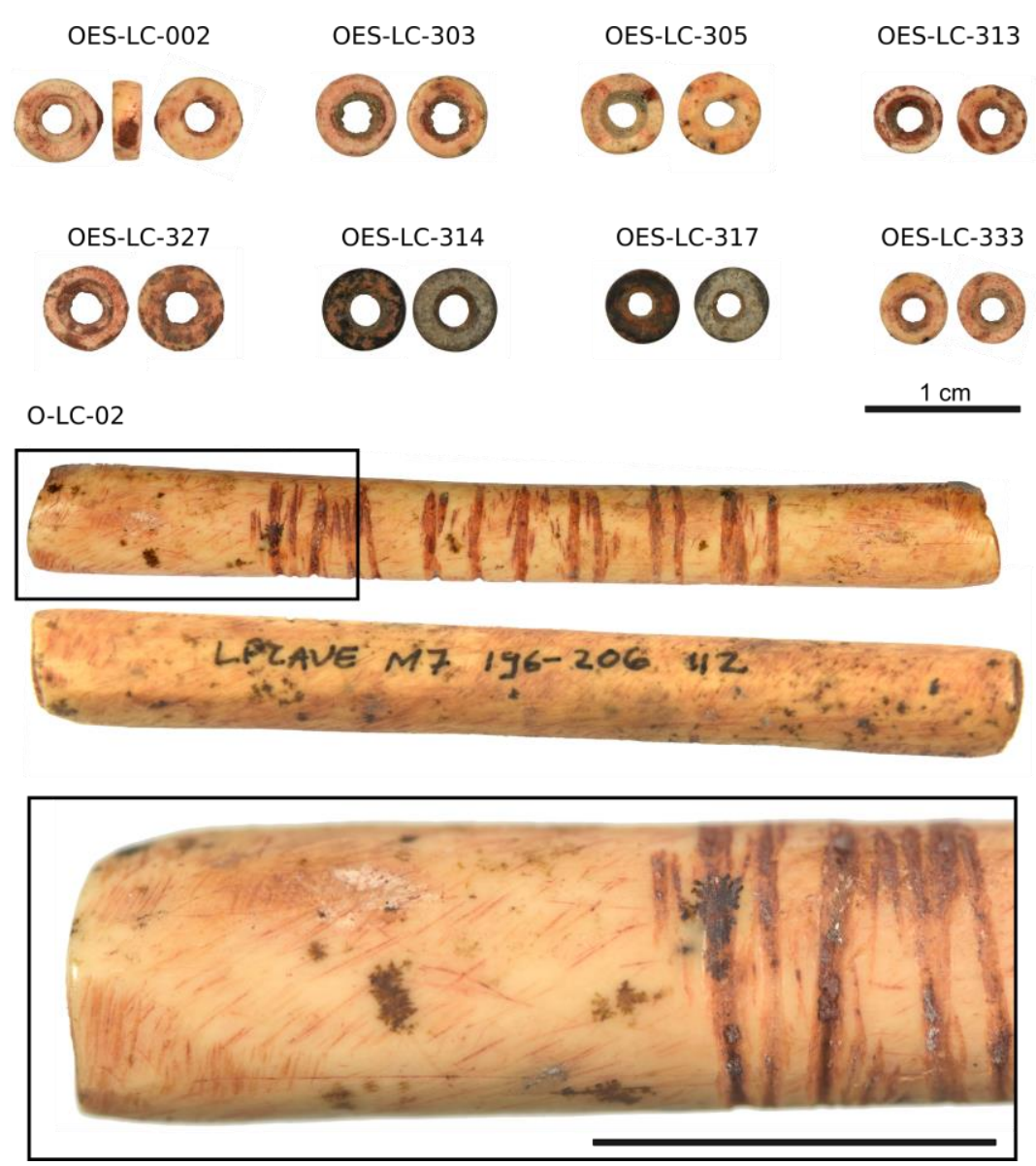

Fig. 7 Selection of beads from Leopard Cave displaying ochre residues. Scales, $1 \mathrm{~cm}$

\section{Distribution of the Material Within the Stratigraphic Sequence}

Table 3 and Fig. 8 sum up the distribution of the ochre fragments and associated grinding stones, beads, and quartz and basalt lithic industries in the stratigraphic complexes and layers. The artifacts were recovered from complex I in layers g and f, spanning from -125 to $-260 \mathrm{~cm}$ (Fig. 8). Complex II and the upper part of complex III are almost sterile of archaeological remains. Layer $\mathrm{f}$ presents a few ochre pieces, some showing possible anthropogenic modifications, and there are also tools and beads with red residues. However, the highest concentration of artifacts is in the "oldest" layer g, located between -185 and $-250 \mathrm{~cm}$ (Fig. 8 and Table 3). This is also where the decorated bone bead was found. While layer $\mathrm{f}$ has delivered one ceramic sherd, possibly due to sediment disturbance, no ceramic sherd was recovered from layer $\mathrm{g}$. 

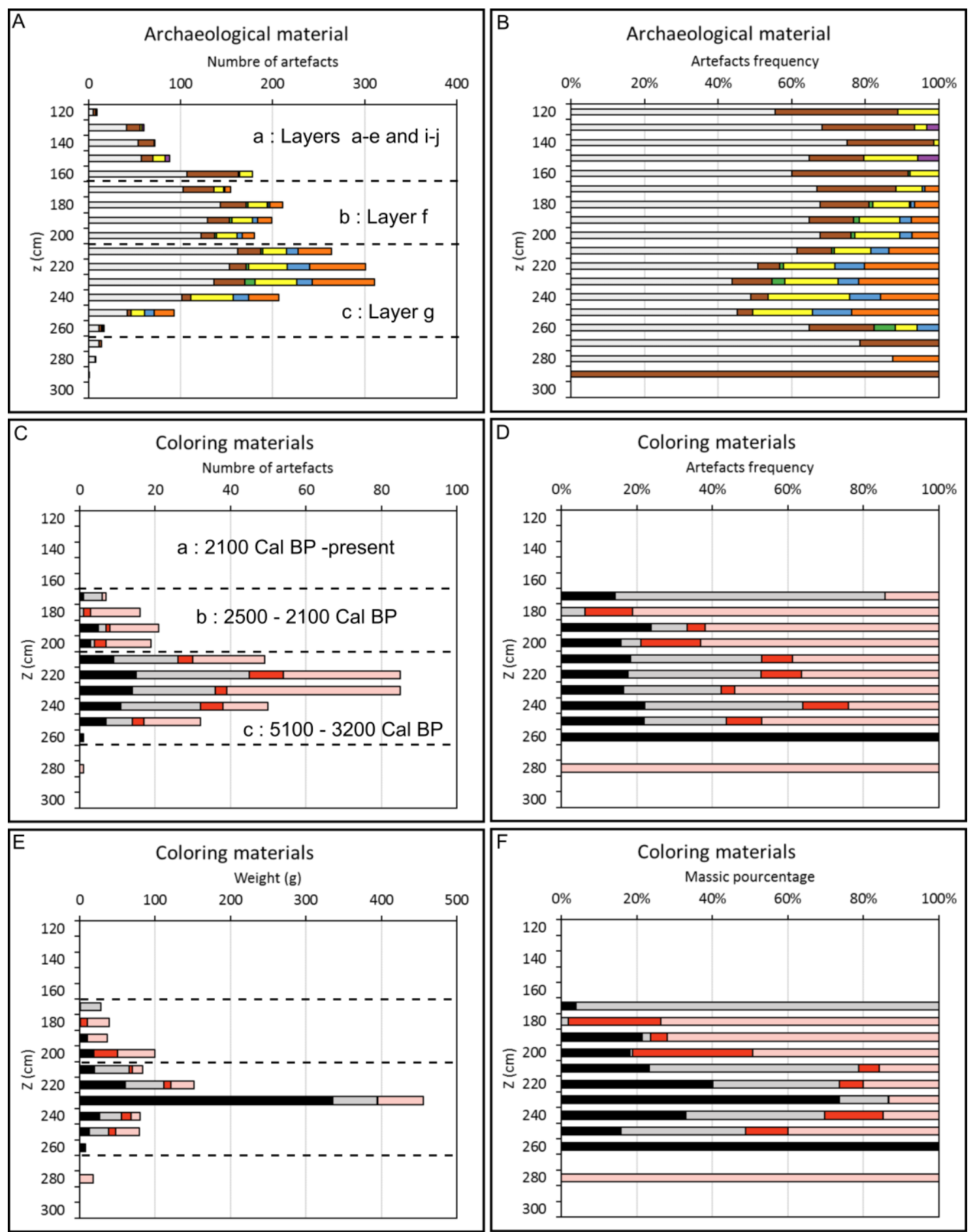

\begin{tabular}{|lll|}
\hline \hline Caption & \\
$\square$ Basalt industries & $\square$ Grinding stones & $\square$ Modified iron oxides \\
$\square$ Faunal remains & $\square$ Modified colouring materials & $\square$ Unmodified ferrrugineous rocks \\
$\square$ Ceramic sherds & $\square$ Unmodified coloring materials & $\square$ Modified ferrugineous rocks \\
$\square$ OES beads & $\square$ Unmodified iron oxides & \\
\hline
\end{tabular}

Fig. 8 Stratigraphic distribution of the materials mentioned in the text at Leopard Cave. a Numerical distribution of various selected archaeological materials. b Frequency distribution of various selected archaeological materials. c, d Numerical and frequency distribution of ochres. e, f Mass distribution and mass percentage of ochres 
When considering the mass distribution of ochre in this stratigraphic complex, it is noteworthy that an iron oxide block weighing $310 \mathrm{~g}$ (LC-130) biased this distribution. Indeed, most of the ochre fragments weighed less than $10 \mathrm{~g}$, with a median weight of $0.8 \mathrm{~g}$. This low value reflects the high fragmentation of the ochre assemblage at Leopard Cave. Moreover, in layer g, potential anthropogenic modifications were identified in over $73 \%$ (220 out of 302) of the ochre fragments recovered (Table 3), confirming the intensive ochre exploitation at the site.

Both kinds of ochre fragments - iron oxides and ferruginous rocks - were recovered in the stratigraphic units $\mathrm{f}$ and $\mathrm{g}$, with no apparent time differentiation. However, rich iron oxides are more abundant in layer $\mathrm{g}$ than in $\mathrm{f}$, although both layers have delivered similar frequencies of lithic industries and faunal remains (Table 3). This difference could indicate either a change of activities performed at the site between the two occupation phases, or a shift in the deposition rate. Nevertheless, from the data gathered, ochre-processing ap-pears to have been an important activity during the occupation phase corresponding to the two archaeological layers.

According to the chronology of the stratigraphic sequence, layer $\mathrm{g}$ is dated between 5,700 and 3,000 BP, despite the unexpected dates of ca 2,100 BP from three charcoal samples (Table 2). Postdepositional activities were most probably responsible for this unexpected young age. Hence, the 2,100 BP date must be considered as the minimum age of the layer and most of the materials above it. This should also be considered as the minimum age of the oldest rock paintings at Leopard Cave (see further discussions below).

Table 3 Stratigraphic distribution of the archaeological material of Leopard Cave within the 3 complexes of the stratigraphic sequence. * Complex III remains largely unexcavated

\begin{tabular}{|c|c|c|c|c|c|c|c|c|c|c|c|c|c|}
\hline \multirow{2}{*}{ 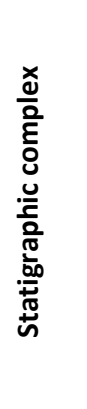 } & \multirow{2}{*}{ 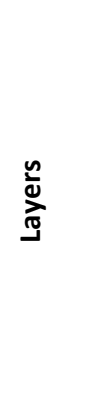 } & $\begin{array}{l}\frac{0}{0} \\
\frac{0}{x} \\
0 \\
0 \\
\underline{\underline{0}}\end{array}$ & & 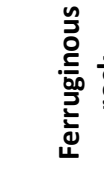 & & & $\frac{n}{8}$ & 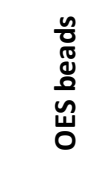 & & \multirow{2}{*}{ 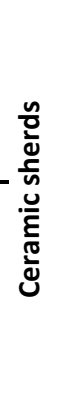 } & \multicolumn{2}{|c|}{ 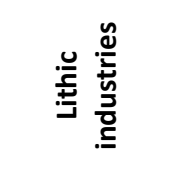 } & \multirow{2}{*}{ 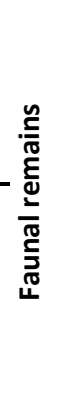 } \\
\hline & & $\begin{array}{l}\bar{\pi} \\
\stackrel{0}{0}\end{array}$ & 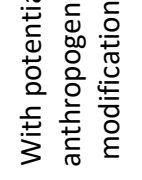 & $\begin{array}{l}\bar{\pi} \\
\stackrel{0}{0} \\
\circ\end{array}$ & 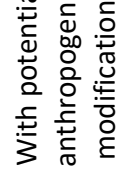 & $\begin{array}{l}\overline{\widetilde{\pi}} \\
\stackrel{0}{0}\end{array}$ & 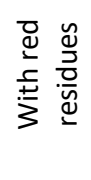 & $\begin{array}{l}\bar{\pi} \\
\stackrel{0}{0} \\
\circ\end{array}$ & 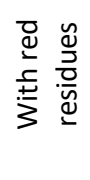 & & $\begin{array}{l}\frac{H}{\pi} \\
\tilde{ల} \\
\infty\end{array}$ & $\begin{array}{l}\frac{N}{0} \\
\frac{\pi}{\sigma} \\
\sigma\end{array}$ & \\
\hline 1 & a-e & 0 & 0 & 0 & 0 & 1 & 1 & 31 & 9 & 7 & 148 & 116 & 104 \\
\hline I & $f$ & 18 & 9 & 45 & 39 & 7 & 2 & 76 & 8 & 1 & 360 & 137 & 100 \\
\hline I & $\mathrm{g}$ & 154 & 97 & 148 & 123 & 17 & 11 & 175 & 43 & 0 & 448 & 137 & 94 \\
\hline II & $\mathrm{k}-\mathrm{I}$ & 0 & 0 & 1 & 1 & 1 & 1 & 0 & 0 & 0 & 9 & 9 & 4 \\
\hline \multicolumn{2}{|c|}{ Total } & 172 & 106 & 194 & 163 & 26 & 15 & 283 & 61 & 8 & 965 & 399 & 302 \\
\hline
\end{tabular}

\section{Discussion}

The technical processes for the production of pigments seem to have five main steps: (1) exploitation/collection of raw materials (ochre) and their subsequent storage; (2) transformation of ochre for the production of color-ing powders; (3) storage of the ochre powder; (4) pos-sible mixing with binders and extenders; and (5) use of the powder/mixture (Dayet 2012; Rifkin 2011; Salomon 2009). At Leopard Cave, at least three of this five-step chaîne opératoire have been identified: collection and storage of raw materials, ochre transformation for the production of coloring powders, and their use. 


\section{Collection and Storage of the Raw Material}

Leopard Cave is not near a natural outcrop of ochre, and these materials could not have been formed from pedogenetic alterations. Hence, the large number of ochre fragments found at the site $(n=366)$ indicates that the raw materials were collected from elsewhere and stored at the site. The diversity of ochres recovered, with a large collection of ferruginous rocks and iron oxides, could be the result of an opportunistic procurement strategy or an important activity of ochre trade from distinct outcrops, as hypothesized by Steele et al. (2016). In the case of an opportunistic procurement strategy, ochre might have been collected during expeditions for other vital goods, with minimum effort to extract them and with a few materials obtained at a time (Couraud 1988, cited by Salomon 2009). The raw material collected came from different places. But these outcrops must be mostly local as they should fall within the region covered by hunter-gatherer populations for their economic activities. In such a procurement strategy, it seems unlikely that ochres would have been collected and transported over very long distances. The fact that many blocks of iron oxides found at Leopard Cave exhibit a smooth outer surface, without any scars from extraction (Fig. 5), supports the hypothesis of an opportunistic collection of the iron oxides at their original ore outcrops. At Leopard Cave, the lithic industries are made mainly of quartz and basalt, also supporting an opportunistic strategy for the use of local raw materials for tool manufacture (Pleurdeau et al. 2012).

As iron oxides and ferruginous rocks might have had different values and natural availability near Leopard Cave, the efforts undertaken to collect these various ochres might have been different. The provenience study of the different ochre fragments recovered at Leopard Cave could help us to understand the mobility pattern of the LSA communities in the area, the territory they exploited for raw materials, and the efforts expended to collect these ochre fragments (Dayet 2012). It will also help us to understand the possible changes in ochre procurement strategies during the Lat-er Stone Age, a topic pioneered by Bernatchez (2008) at Nelson Bay Cave (Western Cape, South Africa). The provenience study of ochre promises to bring new in-sights on the economic behaviors of the LSA populations who occupied Leopard Cave, as well as their social organization.

\section{Ochre Transformations}

The presence of several grinding slabs $(\mathrm{N}=6)$ and handstones $(\mathrm{N}=9)$, as well as the occurrence of red residues and use-wear (e.g., scars) on their surface, demonstrate the intensive pigment processing at Leop-ard Cave during the LSA. These grinding tools might have also been used to grind other materials such as plants, explaining the conservation of red residues in anfractuosities located on the passive faces of the tools. Our observation of the assemblage revealed two distinct chaînes opératoires for producing the pigment powder: fragmentation and grinding, as described above. The recovery of small fragments (less than $1 \mathrm{~mm}$ ) and larger ochre blocks testify to the fragmentation process at the site. The presence of fracturing surfaces on different types of ochre indicates that fragmentation was a com-mon technique for ochre powder production at the Leopard Cave. This is in agreement with Southern African ethnological data, according to which grinding and pounding are the usual treatments of ochre (How 1962; Rudner 1982).

The facets observed on three ferruginous rocks also relate to the grinding technique (Fig. 5). Traces of this technique were only observed on ferruginous rocks that are of soft materials and not on harder iron oxide blocks, an indication of differential ochre treatments based on the degree of hardness. The question then is whether the apparent differential ochre treatment was due to anthropogenic choices or related to a taphonomic bias such as gelifraction and intense heating? The experimental tests on geological iron oxides lead us to support the idea of anthropogenic choice. We noticed that the fragmentation method for iron oxides was based on their hardness. Such a differential treatment raises further questions. Why were all ochres not treated the same way and pounded? The answer to this question may relate to whether the choice to grind some pieces was linked to some kind of symbolic consideration instead of being purely oriented towards technical needs. 
The ochre-related artifacts at Leopard Cave could be connected to various cultural, social, technical, and economic purposes, not all linked to the rock paintings present on the site or in the surroundings (Cristiani et al. 2014; Dayet et al. 2017; d'Errico et al. 2005; Orton 2008). Therefore, the sequence of occupations found at Leopard Cave offers the opportunity to examine whether there were changes in the production and use of the pigments over time.

Some of the ochre fragments and ochre-related arti-facts were found just at the bottom of the painted wall (Fig. 3). And, the minimum age for creating the paintings is consistent with the radiocarbon ages for the layers where the ochre-processing artifacts were found (Table 2). It is tempting, therefore, to say that the ochres were likely used to create the paintings in the shelter. Given the large numbers of rock painting sites around Leopard Cave, it is also possible that ochres found at Leopard Cave were used to produce paintings at some of these other sites (Breuil et al. 1960; Börner 2013; Hollman and Steyn 2003; Nankela 2017; Scherz 1970). It appears that ochres were primarily used for their tinting strength and might have conveyed a magi-cal value, as mentioned in the literature for both ethno-graphic and archaeological contexts (Bleek and Lloyd 1911; How 1962; Rudner 1982; Van der Ryst 1998). In bearing such a magical value, ochres should be considered as a precious raw material. Its treatment, therefore, followed specific steps, as described in Rudner's (1982) review of ethnographic data. The fragmentation and grinding processes, identified at Leopard Cave, could relate to these steps. Identifying the nature of the ochre used to perform the rock paintings could bring new insights regarding rock art production at Leopard Cave and the surrounding area.

However, several other uses should be considered for ochre at Leopard Cave, given the presence of red residues on a wide range of archaeological materials. For example, the red residues present on the beads could have resulted from contact with body paintings, a well-known practice for both social and technical reasons in Southern Africa (How 1962; Rifkin 2012; Rifkin et al. 2015a, b; Rudner 1982); ochred strings on which beads were glued; ochred strings on which the beads were arranged; or clothes on which ochred strings/beads were sewn (Dayet et al. 2017; Vanhaeren et al. 2013). Ethno-graphic data about the ornaments used by !Kung huntergatherers from Botswana attest to the extensive use of OES beads, adhesive, and strings to form complex ornaments (Marshall 1976). Authors have demonstrated the existence of similar personal ornaments within archaeological assemblages of LSA and MSA sites, at

Bushman Rock Shelter (Dayet et al. 2017) and Blombos Cave, respectively (Vanhaeren et al. 2013). At Leopard Cave, beads with red residues on their ventral and dorsal sides (e.g., OES-LC-313, OES-LS-314, and OES-LC317; Fig. 7) could have been glued together to form rigid lines or ring-shaped ornaments. Beads with residues within their inner lateral sides could have been similarly arranged and glued on a string (e.g., OES-LC-303 and OES-LC-313). Likewise, the bone tube (O-LC-02) bead could have been part of a larger ornament arranged on a string. The red residues on the external sides of the beads may have resulted from contacts with an ochred body. In all cases, the red residues on the ornaments are indicative of the past cultural, social, and technical practices of ochre exploitation at Leopard Cave.

Indeed, body paintings and personal ornaments generally convey complex social information (Vanhaeren and d'Errico 2003, 2005; Vanhaeren et al. 2006, 2013; Rigaud et al. 2014). They could be markers of status or individual/community identity in everyday life or during specific events of high symbolic importance (Rudner 1982). The use of ochre for body paintings possibly also served technical purposes, such as insect repellent or sun protection (Rifkin 2012; Rifkin et al. 2015a, b). All of these further highlight the difficulty of discussing ochre uses at an inhabited rock art site. This difficulty of interpretation is further intensified by other possible ochre uses that do not leave archaeological traces but are known from ethnographic studies (e.g., hide tanning; Kewanwytewa and Bartlett 1946; Webley 2005). Ethnographic data allow us to consider the existence of such use in LSA populations (Blauer 1999), but the Leopard Cave ochres do not bear direct evidence for such use since treated skin, like most organic materials, are not preserved in the archaeological context. 


\section{Chronological Constraints}

From a stylistic point of view, the paintings at Leopard Cave are similar to the other Namibian rock art paintings. Such monochrome fine-lines paintings are encountered in various sites in Namibia, especially at other excavated sites of the northwestern Erongo Mountain, such as Fackelträger (Richter 1991; Wendt 1972), Rain Cloud (Breuil et al. 1960), and Etemba (Wendt 1972). The paintings found at Leopard Cave seem to be of the same cultural tradition as those of these other sites in the Erongo area (Nankela 2017).

Although archaeological raw blocks of ochres were found at Leopard Cave in levels ranging from - 140 to $300 \mathrm{~cm}$, their highest concentration was observed between -190 and $-230 \mathrm{~cm}$ (Fig. 8). The latter corre-sponds to archaeological layers $\mathrm{f}$ and $\mathrm{g}$, dated between 3,500 $\pm 100 \mathrm{cal} \mathrm{BP}$ (Beta-236964) and 2,000 $\pm 150 \mathrm{cal}$ BP (SacA51308). The youngest date of these layers was obtained from a charcoal sample located near a grinding slab and a handstone showing red traces that might have been displaced vertically into older layers due to postdepositional biologic agents; for example, the localized burrows. The age obtained from it should be considered as the minimum age for the use of the in situ grinding slab and handstone.

The red pigment on the wall of the cave at levels previously buried under the sediment provides a terminus ante quem for the creation of some of the paintings. As demonstrated by Mauran et al. (2019), the red traces found on the wall are not from the stains of sediment; neither are they a natural coloration of the granite. Rather, they correspond to the anthropogenic use of iron oxide pigments. These traces of pigments on the wall are either the remains of a red painting that is completely altered or traces of weathered pigments from paintings drawn above (Fig. 3). Therefore, the dating of this archaeological layer to 2,100 \pm 100 cal BP provides an age for the covering of these traces by sediments, not for the creation of the painting.

The present findings at Leopard Cave indicate a tradition of ochre processing between 3,500 and 2,000 BP, during the Wilton pre pottery period known at other Namibian sites for the extensive use of ochres (Richter 1991, 2002). The highest number of ochre fragments was discovered in layer g, where no ceramic sherd was present (Fig. 8 and Table 3). This layer is dated between 3,100 and 5,100 cal BP, corresponding to the Wilton preceramic period (Richter 2002). These dates are similar to those obtained at other sites in the Erongo Mountains such as Fackelträger and Etemba (Richter 1991; Wendt 1972), Rain Cloud (Pleurdeau, personal communication), Striped Giraffe (Sandelowsky and Viereck 1969), and Phillips Cave (Martin and Mason 1954) in which archaeological ochres have also been recovered (Table 1, Fig. 1, and Online Resource 1). All of these confirm the existence of a long tradition of ochre processing in the Erongo Mountains, and more generally, in northcentral Namibia. Some of these were related to the execution of rock art paintings in the region. The minimum age of Leopard Cave paintings $(2,100 \pm 100 \mathrm{cal} \mathrm{BP})$ is slightly younger than the minimum age obtained in the Brandberg at Amis 10/Riesenhöhle (Breunig 2003; Pager and Breunig 1989), but it still falls in the pre pottery period proposed by Richter (1991, 2002).

Based on stylistic considerations of the rock art paintings and the archaeological artifacts recovered from the Namibian painted sites, Richter $(1991,2002)$ proposed 6,000-1,000 cal BP as the main period for the creation of the Namibian paintings. He divided this into two periods: pre pottery $(6,000-2,000 \mathrm{cal} \mathrm{BP})$ and post pottery $(2,000-1,000$ cal BP). According to the assemblages recovered at different rock art sites, the pre pottery stage corresponds to the period with most intensive activities for ochre processing and the execution of most of the Namibian LSA rock art (Richter 1991, 2002). The sole terminus ante quem, coming from the Brandberg site of Amis 10 (Riesenhöhle), falls with-in this period. Indeed, at this site, the exfoliated fragment of paintings derived from a layer dated to 2,760 \pm 50 cal BP (Breunig 2003; Pager and Breunig 1989). The remaining challenge is to more securely link the rock art paintings of Leopard Cave in relation to the ochre of the archaeological contexts.

\section{Future Directions}

Leopard Cave is unique because of the documentation of the different chaîne opératoire for ochre processing and usage (raw blocks, tools bearing red residues, colored OES beads, and paintings) in the archaeological contexts. Although severely altered, the paintings at the cave still present characteristics similar to the rock 
paintings already studied in western Namibia (Breuil et al. 1960; Nankela 2017; Scherz 1970; Vallverdu et al. 1979). Their alteration is mainly caused by water leakages that led to the dissolution of the pigments and the formation of authigenic crusts identified as calcium sulfate, such as gypsum and calcium oxalate (Mauran et al. 2019). These leakages all originate from various cracks found in the granite bedrock. Experiments are currently in progress to radiocarbon date the alterations covering the paintings at Leopard Cave, as one of the steps needed to overcome some of the chronological constraints in the present study (Dumoulin et al. in press). The ongoing effort to correlate the chemical attributes of the pigments in the rock paintings and on the archaeological tools promises to shed more light on the processes for the creation of the paintings and their subsequent alterations. Indeed, if the coloring agents discovered in the archaeological layers and the rock paintings correlate in terms of chemical composition, this would provide strong evidence for indirect dating of the rock paintings (Beck et al. 2012; Bednarik 2002; Lebon et al. 2014, 2018, 2019). Research about this correlation is partly hardened by the semantic discrepancies of the term "ochre" for the different actors involved in this research. Such issue calls for moving to less problematic terms, carefully selected in agreement with all disciplines involved in the study of these materials.

There is also an ongoing study of the microsamples of the rock art paintings, red residues found on the tools, and the ochre fragments using scanning electron microscopy (SEM), particle-induced X-ray emission (PIXE), and laser ablation inductively coupled plasma mass spectrometry (LA-ICP-MS). These analyses will pro-vide new insights on the technical processes for the production and use of pigments at Leopard Cave (see Hahndiek 2014; Hughes and Solomon 2000). We plan to include other Erongo LSA rock art sites in our future studies. These include Rain Cloud, Giraffe Shelter, and Seal Shelter (Table 1, Fig. 1), where test pits already show the promise of documenting pigment production activities. This multisite study will provide critical in-sights into the pattern of LSA population mobility, their interactions with the environment, and the values they placed on ochre.

\section{Conclusion}

Our study presents an exceptional archaeological assemblage connected to the processing of ochres at Leopard Cave in the Erongo Mountains, Namibia. The rich-ness of this assemblage derives from the number of blocks of raw ochre and the traces of red residues on artifacts, tools, and ornaments. There is strong evidence for a long tradition of ochre processing at the site of Leopard Cave, and this was possibly connected to the rock paintings at the site. At least two distinct chaînes opératoires for ochre processing were documented, and these were possibly used for various purposes, including the creation of rock paintings, body painting, and abrading agents. The study also presents a new chronological framework for the rock art paintings at Leopard Cave, showing that the paintings were rendered between 3,600 and 2,000 cal BP, during the pre pottery LSA period.

This study is part of the renewed rock art studies in Southern Africa. It paves the way for new ochre and rock art analyses, to understand the technological, sociocultural, and chronological development of LSA rock art and ochre usage in the Erongo Mountains of Namibia. The study also calls for more investigations on ochre uses at other Southern African LSA rock art sites.

\footnotetext{
Acknowledgments The authors are very grateful to Ms. and Mr. Rust and their family for their kind permission to access and excavate the archaeological site of Leopard Cave, located on their farm. This research was supported by grants from the French Ministry of Foreign Affairs through the project "MANAM: Mis-sion Archéologique en NAMibie," the LaBex BCDiv (Biological and Cultural Diversity) for the project "Dynamique des peuples en Namibie à l'Holocène - NAMIBIE (Windhoek, Erongo)" both directed by D.P., the Observatoire des Patrimoines de Sorbonnes universités (OPUS) through the project "APaNam: Art rupestre et Patrimoine en Namibie" directed by M.L. Research by G.M. was funded by the Chaire Polyre of Sorbonne Universités. Permission to conduct research was granted by the National Heritage Council of Namibia (permit 11/2015 and permit renewal 04/2017 given to D.P.). We are grateful for the support of this institution, the National Museum of Namibia, and the French Embassy in Na-mibia. Finally, the authors wish to express their sincere gratitude to Professor Lyn Wadley (ESI, University of the Witwatersrand) for revising the English and the anonymous reviewers for their com-ments and suggestions.
}

Compliance with Ethical Standards

Conflict of Interest The authors declare that they have no conflict of interest. 


\section{References}

Barham, L. S. (2002). Systematic pigment use in the Middle Pleistocene of south-central Africa. Current Anthropology, 43(1), 181-190.

Beck, L., Salomon, H., Lahlil, S., Lebon, M., Odin, G., Coquinot, Y., \& Pichon, L. (2012). Non-destructive provenance differ-entiation of prehistoric pigments by external PIXE. Nuclear Instruments and Methods in Physics Section B, 273, $173-177$.

Bednarik, R. (2002). The dating of rock art: A critique. Journal of Archaeological Science, 29, 1213-1233.

Bernatchez, J. A. (2008). Geochemical characterization of archae-ological ochre at Nelson Bay Cave (Western Cape Province), South Africa. The South African Archaeological Bulletin, 63(187), 3-11.

Blauer, E. (1999). African elegance. New York: Rizzoli International Publications.

Bleek, W. H. I., \& Lloyd, L. (1911). Specimens of Bushman folklore. London: Allen.

Blümel, W., Emmermann, R., \& Huser, K. (1979). Der Erongo- Geowissenschaftliche beschreibung und deutung eines sudwestafrikanischen vulkankomplexes. Windhoek: VerlagSWA Wissenschaft Gesell.

Bonneau, A., Pearce, D. G., \& Pollard, A. M. (2012). A multi-technique characterization and provenance study of the pigments used in San rock art, South Africa. Journal of Archaeological Science, 39(2), 287-294.

Bonneau, A., Pearce, D. G., Mitchell, P. J., Arthur, C., Higham, T., Lamothe, M., \& Arsenault, D. (2014). Comparing painting pigments and subjects: The case of white paints at the Metolong dam (Lesotho). In R. B. Scott, D. Braekmans, M. Carremans, \& P. Degryse (Eds.), 39th International Symposium on Archaeometry, 28 May-1 June 2012, Leuven, Belgium: Proceedings (pp. 319-323). Leuven: Centre for Archaeological Sciences.

Bonneau, A., Pearce, D., Mitchell, P., Staff, R, Arthur, C., Mallen, L., et al. (2017). The earliest directly dated rock paintings from southern Africa: New AMS radiocarbon dates. Antiquity, 91(356), 322-333.

Börner, V. (2013). Die Uberprufune der Schamanismus-Theorie anhand ausgewahlter Felsmalerien ausdem Erongo Gebirge, Namibia. Masters thesis, Goethe-University, Frankfurt.

Breuil, H. (1955). The white lady of the Brandberg. Paris: Trianon Press.

Breuil, H., Boyle, M. E., Scherz, E. R., \& Strey, R. G. (1960). Anibib \& Omandumba, and other Erongo sites. Clairveaux: Calouste Gulbenkian Foundation.

Breunig, P. (2003). Der Brandberg. Untersuchungen zur Besiedlungsgeschichte eines Hochgebirges in Namibia. Africa Praehistorica 17. Köln: Heinrich-Barth-Institut.

Breunig, P. (2019). Destroyed rock art: Signs of conflict between prehistoric hunter-gatherers groups on the edge of northwest-ern Namibia's Namib desert. In C. Alday \& S. Morisset (Eds.), Desert archaeology (pp. 89-121). Cambridge: Archaeological Review from Cambridge.

Breunig, P., Behringer, J., Fels, M., \& Maidhof, J. (2018). West of the best: Rock art and archaeological discoveries in the Doro! Nawas region of northwest Namibia. Acta Archaeologica, 89(1), 174-192.

Bronk Ramsey, C. (2009). Bayesian analysis of radiocarbon dates. Radiocarbon, 51(1), 337-360.

Challis, S. (2012). Creolisation on the nineteenth-century frontiers of southern Africa: A case study of the AmaTola 'Bushmen'in the Maloti-Drakensberg. Journal of Southern African Studies, 38(2), 265-280.

Challis, S. (2016). Re-tribe and resist: The ethnogenesis of a creolised raiding band in response to colonisation. In C. Hamilton \& N. Leibhammer (Eds.), Tribing and untribing the archive: Identity and the material record in southern KwaZulu-Natal in the late independent and colonial periods (pp. 282-299). Pietermaritzburg: University of KwaZuluNatal Press.

Conard, N. J., Breunig, P., Gonska, H., \& Marinetti, G. (1988). The feasibility of dating rock paintings from Brandberg, Namibia, with 14C. Journal of Archaeological Science, 15, 463-466.

Couraud, C. (1988). Pigments utilisés en Préhistoire. Provenance, préparation, mode d'utilisation. L'Anthropologie, 92(1), $17-28$.

Cristiani, E., Živaljević, I., \& Borić, D. (2014). Residue analysis and ornament suspension techniques in prehistory: Cyprinid pharyngeal teeth beads from Late Mesolithic burials at Vlasac (Serbia). Journal of Archaeological Science, 46, 292-310.

d'Errico, F., Henshilwood, C., Vanhaeren, M., \& van Niekerk, K. (2005). Nassarius kraussianus shell beads from Blombos cave: Evidence for symbolic behaviour in the Middle Stone Age. Journal of Human Evolution, 48(1), 3-24.

d'Errico, F., Moreno, R. G., \& Rifkin, R. F. (2012). Technological, elemental and colorimetric analysis of an engraved ochre fragment from the Middle Stone Age levels of Klasies River Cave 1, South Africa. Journal of Archaeological Science, 39(4), 942-952.

Dayet, L. (2012). Matériaux, transformations et fonctions de l'ocre au Middle Stone Age: le cas de Diepkloof Rock Shelter dans le contexte de l'Afrique australe. Ph.D. disser-tation. Université de Bordeaux I, Bordeaux.

Dayet, L., Texier, P. J., Daniel, F., \& Porraz, G. (2013). Ochre resources from the Middle Stone Age sequence of Diepkloof rock shelter, Western Cape, South Africa. Journal of Archaeological Science, 40(9), 3492-3505. 
Dayet, L., Erasmus, R., Val, A., Feyfant, L., \& Porraz, G. (2017). Beads, pigments and early Holocene ornamental traditions at Bushman rock shelter, South Africa. Journal of Archaeological Science: Reports, 13, 635-651.

Dubreuil, L., \& Savage, D. (2014). Ground stones: A synthesis of the use-wear approach. Journal of Archaeological Science, $48,139-153$.

Dumoulin, J.P., Lebon, M., Caffy, I., Mauran, G., Nankela, A., Pleurdeau, D., Delqué-Količ, E., Moreau, C., Perron, M., Sieudat, M., Thellier, B., \& Beck L. (in press). Calcium oxalate radiocarbon dating: Preliminary dating tests for rock paintings from Leopard Cave site in Erongo Mountains, Namibia, Radiocarbon.

Eastwood, E. B., \& Smith, B. W. (2005). Fingerprints of the Khoekhoen: Geometric and handprinted rock art in the Central Limpopo Basin, southern Africa. Goodwin Series, 9, 63-76.

Ebeling, J. R., \& Rowan, Y. M. (2004). The archaeology of the daily grind: Ground stone tools and food production in the southern Levant. Near Eastern Archaeology, 67(2), 108- 117.

Hahndiek, C. T. (2014). Of pigments and paint: Quantifying ochre and rock art in the Cederberg (Western Cape, South Africa). Ph.D. dissertation, University of Cape Town, South Africa.

Harman, J. (2008). Digital enhancement of pictographs from Baja California. In Simposium Internacional de Arte Rupestre (pp. 104-134), La Habana: Instituto Cubano de Antropología, Convento San Francisco de Asís.

Hayes, E. H., Cnuts, D., Lepers, C., \& Rots, V. (2017). Learning from blind tests: Determining the function of experimental grinding stones through use-wear and residue analysis. Journal of Archaeological Science: Reports, 11, $245-260$.

Henshilwood, C. S. (2002). Emergence of modern human behav-ior: Middle Stone Age engravings from South Africa. Science, 295(5558), 1278-1280.

Henshilwood, C. S., D’Errico, F., \& Watts, I. (2009). Engraved ochres from the Middle Stone Age levels at Blombos Cave, South Africa. Journal of Human Evolution, 57(1), $27-47$.

Henshilwood, C., D’Errico, F., van Niekerk, K. L., Dayet, L., Queffelec, A., \& Pollarolo, L. (2018). An abstract drawing from the 73,000 year-old at Blombos Cave, South Africa. Nature, 562, 115-118.

Hodgskiss, T. (2010). Identifying grinding, scoring and rubbing use-wear on experimental ochre pieces. Journal of Archaeological Science, 37(12), 3344-3358.

Hodgskiss, T. (2012). An investigation into the properties of the ochre from Sibudu, KwaZulu-Natal, South Africa. Southern African Humanities, 24(1), 99-120.

Hodgskiss, T. (2013). Ochre use in the Middle Stone Age at Sibudu, South Africa: Grinding, rubbing, scoring and engraving. Journal of African Archaeology, 11(1), 75-95.

Hodgskiss, T. (2020). Ochre use in the Middle Stone Age. In M. Aldenderfer et al. (Eds.), Oxford research encyclopedia of anthropology. Oxford: Oxford University Press.

Hogg, A. G., Hua, Q., Blackwell, P. G., Niu, M., Buck, C. E., Guilderson, T. P., Heaton, T. J., Palmer, J. G., Reimer, P. J., Reimer, R. W., Turney, C. S. M., \& Zimmerman, S. R. H. (2013). SHCal13 southern hemisphere calibration, 0-50,000 years cal BP. Radiocarbon, 55(4), 1889-1903.

Holl, A. F. C. (2017). Beyond shamanism: Dissecting the painting from Snake Rock in Namibia. Journal of Culture, 1, 2735.

Hollmann, J., \& Steyn, W. (2003). A report on the rock paintings in the Erongo Mountain, Erongo Region: Karibib, Omaruru District, Namibia. RARI Field trip 8-28 June 2003. Unpublished Report.

How, M. W. (1962). The mountain bushmen of Basutoland.Pretoria: JL van Schaik.

Hughes, J. C., \& Solomon, A. (2000). A preliminary study of ochres and pigmentaceous materials from KwaZulu-Natal, South Africa: Towards an understanding of San pigment and paint use. Southern African Humanities, 12(1), 15-31.

Kewanwytewa, J., \& Bartlett, K. (1946). Hopi moccasin making.Plateau, 19, 21-28.

Kinahan, J. (1990). Four thousand years at the Spitzkoppe: Changes in settlement and landuse on the edge of the Namib Desert. Cimbebasia, 12, 1-14.

Kinahan, J. (2000). Dâures, the burning mountain-issues of research and conservation in the Brandberg of Namibia. Cimbebasia Memoir, 9, 1-16.

Kinahan, J. (2010). The rock art of /Ui-//aes (Twyfelfontein) Namibia's first World Heritage Site. Adoranten, 39-51

Kinahan, J. (2018). A ritual assemblage from the third millennium BC in the Namib Desert and its implications for the archae-ology and rock art of shamanic performance. Azania: Archaeological Research in Africa, 53(1), 40-62.

Le Quellec, J. L. (2018) The rock art of sub-Saharan Africa. The Oxford handbook of the archaeology and anthropology of rock art. Oxford: Oxford University Press. https://doi. org/10.1093/oxfordhb/9780190607357.001.0001/oxfordhb9780190607357-e-25. Accessed 8 January 2020.

Le Quellec, J.-L., Harman, J., Defrasne, C., \& Duquesnoy, F. (2013). Dstretch® et l'amélioration des images numériques: Applications à l'archéologie des images rupestres. Les Cahiers de l'AARS, 16, 177-198.

Lebon, M., Beck, L., Grégoire, S., Chiotti, L., Nespoulet, R., Menu, M., \& Paillet, P. (2014). Prehistoric pigment characterization of the Abri Pataud rock-shelter (Dordogne, France). Open Journal of Archaeometry, 2, 90-94.

Lebon, M., Pichon, L., \& Beck, L. (2018). Enhanced identification of trace element fingerprint of prehistoric pigments by PIXE mapping. Nuclear Instruments and Methods in Physics Research Section B: Beam Interactions with Materials and Atoms, 417, 91-95.

Lebon, M., Gallet, X., Bondetti, M., Pont, S., Mauran, G., Walter, P., Bellot-Gurlet, L., Puaud, S., Zazzo, A., Forestier, H., Auetrakulvit, P., \& Zeitoun, V. (2019). Characterization of painting pigments and ochers associated to Hoabinhian ar- 
chaeological context at the rock paintings site of Doi Pha Kan (Thailand). Journal of Archaeological Science: Reports, 26, 101855.

Lenssen-Erz, T. (2004). The landscape setting of rock-painting sites in the Brandberg, Namibia: Infrastructure, Gestaltung, use and meaning. In G. Nash \& C. Chippindale (Eds.), The figured landscapes of rock art (pp. 131-150). Cambridge: Cambridge University Press.

Marshall, L. (1976). The !Kung of Nyae Nyae. Cambridge:Harvard University Press.

Martin, H., \& Mason, R. (1954). The test trench in the Phillips cave, Ameib, Erongo mountains, South West Africa. The South African Archaeological Bulletin, 9(36), 148-151.

Mauran, G., Lebon, M., Détroit, F., Caron, B., Nankela, A., Pleurdeau, D., \& Bahain, J. J. (2019). First in situ pXRF analyses of rock paintings in Erongo, Namibia: Results, current limits and prospects. Archaeological and Anthropological Sciences, 11(8), 4123-4145.

Mazel, A. D. (1993). Dating the Collingha shelter rock paintings.Pictogram, 6(2), 33-35.

Mazel, A. D., \& Watchman, A. L. (1997). Accelerator radiocarbon dating of Natal Drakensberg paintings: Results and implica-tions. Antiquity, 71(272), 445-449.

Moyo, S., Mphuthi, D., Cukrowska, E., Henshilwood, C. S., van Niekerk, K., \& Chimuka, L. (2016). Blombos cave: Middle Stone Age ochre differentiation through FTIR, ICP OES, ED XRF and XRD. Quaternary International, 404, $20-29$.

Nankela, A. M. (2015). Rock art research in Namibia: A synopsis.Africana Studia, 24(1), 39-55.

Nankela, A.M. (2017). Rock art and landscape: An empirical analysis in the content, context and distribution of the rock art sites in Omandumba East and West, Erongo Region Namibia. Ph.D. dissertation, Universidade de Tomar, Tomar.

Orton, J. (2008). Later Stone Age ostrich eggshell bead manufac-ture in the Northern Cape, South Africa. Journal of Archaeological Science, 35, 1765-1775.

Ouzman, S. (2005). The magical arts of a raider nation: central So ut h Afr ica's Ko r an a r oc k ar t. S o u t h A f r i c a $\mathrm{n}$ Archaeological Society Goodwin Series, 9, 101-113.

Pager, H. (1993). The rock paintings of the Upper Brandberg. Part Hungorob Gorge. Köln: Heinrich-Barth Institute.

Pager, H. (1995). The rock paintings of the Upper Brandberg: Part 3: Southern Gorges. Köln: Heinrich-Barth Institute.

Pager, H. (1998). The rock paintings of the Upper Brandberg. Part Umuab and Karoab Gorges. Köln: Heinrich-Barth Institute.

Pager, H. (2001). The rock paintings of the Upper Brandberg. Part Naib Gorge (A) and the Northwest. Köln: Heinrich-Barth Institute.

Pager, H. (2005). The rock paintings of the Upper Brandberg. Part Naib Gorge (B) and the Northwest. Köln: Heinrich-Barth Institute.

Pager, H. (2006). The rock paintings of the upper Brandberg: Part 6, Naib (B), Circus and Dom Gorges. Köln: HeinrichBarth Institute.

Pager, H., \& Breunig, P. (1989). The rock paintings of the Upper Brandberg Part 1: Amis Gorge. Köln: Heinrich -Barth Institute.

Pleurdeau, D., Imalwa, E., Détroit, F., Lesur, J., Veldman, A., Bahain, J. J., \& Marais, E. (2012). Of sheep and men: Earliest direct evidence of caprine domestication in Southern Africa at Leopard Cave (Erongo, Namibia). PLoS One, 7(7), e40340.

Pomiès, M. P., Menu, M., \& Vignaud, C. (1999). TEM observa-tions of goethite dehydration: Application to archaeological samples. Journal of the European Ceramic Society, 19, 1605-1614.

Pradeau, J. V. (2015). Lesmatières colorantes au sein des systèmes techniques et symboliques au Néolithique (VIe et Ve millènaires BCE) dans l'arc liguro-provençal. Ph.D. disser-tation, Université Nice Sophia Antipolis, Nice.

Prinsloo, L. C., Barnard, W., Meiklejohn, I., \& Hall, K. (2008). The first Raman spectroscopic study of San rock art in the Ukhahlamba Drakensberg Park, South Africa. Journal of Raman Spectroscopy, 39(5), 646-654.

Richter, J. (1988). Studien zur Urgeschichte Namibias. Kurzfassung. Archäologishe Informationen, 11(2), $215-217$.

Richter, J. (1991). Studien zur Urgeschichte Namibias. Köln: Heinrich Barth-Institut.

Richter, J. (1995). Prähistorische Felskunst und Besiedlung in Zentralnamibia. Archäologische Informationen, 18(1), 19- 30.

Richter, J. (2002). The giraffe people: Namibia's prehistoric art-ists. In T. Lenssen-Erz \& U. Tegtmeier (Eds.), Tides of the desert: Contributions to the archaeology and environmental history of Africa in honour of Rudolf Kuper (pp. 523-534). Köln: Heinrich-Barth-Institut.

Richter, J., \& Vogelsang, R. (2008). Rock art in North-Western Central Namibia: Its age and cultural background. In C. Limprecht \& M. Biesele (Eds.), Heritage and cultures in modern Namibia: In-depth views of the country (pp. 37-46). Goettingen: Klaus Hess Publishers.

Rifkin, R. F. (2011). Assessing the efficacy of red ochre as a prehistoric hide tanning ingredient. Journal of African Archaeology, 9(2), 131-158.

Rifkin, R. F. (2012). Processing ochre in the Middle Stone Age: Testing the inference of prehistoric behaviours from actualistically derived experimental data. Journal of Anthropological Archaeology, 31(2), 174-195.

Rifkin, R. F., Dayet, L., Queffelec, A., Summers, B., Lategan, M.,D’Errico, F. (2015a). Evaluating the photoprotective effects of ochre on human skin by in vivo SPF assessment: Implications for human evolution, adaptation and dispersal. PLoS One, 10(9), e0136090.

Rifkin, R. F., D’Errico, F., Dayet-Boulliot, L., \& Summers, B.(2015b). Assessing the photoprotective effects of red ochre: On human skin by in vitro laboratory experiments. South African Journal of Science, 111(3/4), 1-8. 
Rifkin, R. F., Prinsloo, L. C., Dayet, L., Haaland, M. M., Henshilwood, C. S., et al. (2016). Characterising pigment on 30,000-year-old portable art from Apollo 11 Cave, Karas Region, southern Namibia. Journal of Archaeological Science: Reports, 5, 336-347.

Rigaud, S., Vanhaeren, M., d'Errico, F., \& Queffelec, A. (2014). The way we wear makes the difference: Residue analysis applied to Mesolithic personal ornaments from Hohlenstein-stadel (Germany). Archaeological and Anthropological Sciences, 6, 133-144.

Rosso, D. E., D’Errico, F., \& Queffelec, A. (2017). Patterns of change and continuity in ochre use during the late Middle Stone Age of the Horn of Africa: The Porc-Epic Cave record. PLoS One, 12(5), e0177298.

Rudner, I. (1982). Khoisan pigments and paints and their rela-tionship to rock paintings. Annals of the South African Museum, v. 87. Cape Town: South African Museum.

Salomon, H. (2009). Les matières colorantes au début du Paléolithique supérieur: sources, transformations et fonctions. Ph.D. dissertation, Université Bordeaux I.

Salomon, H., Vignaud, C., Coquinot, Y., Beck, L., Stringer, C., Strivay, D., \& D'errico, F. (2012). Selection and heating of colouring material in the Mousterian level of Es-Skhul (c. 100,000 years BP, Mount Carmel, Israel). Archaeometry, 54(4), 698-722.

Salomon, H., Coquinot, Y., Beck, L., Vignaud, C., Lebon, M., Odin, G., Mathis, F., \& Julien, M. (2014). Stratégies spécialisées d'acquisition de pigments rouges durant le châtelperronien de la grotte du renne à Arcy-sur-Cure (Yonne, France). In P. Paillet (Ed.), Les arts de la préhistoire: Micro-analyses, mises en contextes et conserva-tion; actes du colloque "Micro-analyses et datations de l'art préhistorique dans son contexte archéologique", MADAPCA, Paris, 1618 Novembre 2011 (pp. 125-133). Villefranche-de-Rouergue: Grapho 12.

Salomon, H., Vignaud, C., Lahlil, S., \& Menguy, N. (2015). Solutrean and Magdalenian ferrugineous rocks heat treat-ment: Accidental and/or deliberate action? Journal of Archaeological Science, 55, 100-112.

Sandelowsky, B., \& Viereck, A. (1969). Supplementary report on the archaeological expedition of 1962 to the Erongo Mountains of South West Africa. Cimbebasia, 1(1), 1-43.

Scherz, E. R. (1970). Felsbilder in Südwest-Afrika. Köln: Böhlau Verlag.

Si Ammour, S. (2016). Approche technologique des perles en tests d'oeuf d'autruches de l'abri de Leopard Cave (Damaraland, Namibie). Master's thesis, Université de Paris 1, Panthéon-Sorbonne.

Smith, B., Ouzman, S., Chippindale, C., Dowson, T., Mitchell, P., Morris, D., et al. (2004). Taking stock: Identifying Khoekhoen herder rock art in Southern Africa. Current Anthropology, 45(4), 499-526.

Steele, T. E., Mackay, A., Fitzsimmons, K. E., Igreja, M., Marwick, B., Orton, J., et al. (2016). Varsche Rivier 003: A Middle and Later Stone Age site with Still Bay and Howiesons Poort assemblages in Southern Namaqualand, South Africa. PaleoAnthropology, 2016, 100-163.

Tournié, A., Prinsloo, L. C., Paris, C., Colomban, P., \& Smith, B. (2011). The first in situ Raman spectroscopic study of san rock art in South Africa: Procedures and preliminary results. Journal of Raman Spectroscopy, 42(3), 399-406.

Vallverdu, R. V., Boscovich, E. S., \& Escalera, J. E. (1979). Nouvelles peintures du massif de l'Erongo S.W.A (Namibie), Drotskie Rock, Anibib I. Bulletin de la Société Préhistorique de l'Ariège, 34, 91-113.

Van der Ryst, M. M. (1998). The Waterberg plateau in the northern province, Republic of South Africa, in the Later Stone Age. Oxford: Archaeopress.

Van Rijssen, W. J. (1990). Analysis of South African rock art pigments by X-ray fluorescence spectroscopy (EDS). The South African Archaeological Bulletin, 45(151), 58-59.

Vanhaeren, M., \& d'Errico, F. (2005). Grave goods from the Saint-Germain-la-Riviere burial: Evidence for social inequal-ity in the upper Palaeolithic. Journal of Anthropological Archaeology, 24, 117-134.

Vanhaeren, M., \& d'Errico, F. (2003). Le mobilier funéraire de la Dame de Saint-Germain-la- Rivière (Gironde) et l'origine paléolithique des inégalités. Paleo, 15, 2-59.

Vanhaeren, M., d'Errico, F., Stringer, C., James, S., Todd, J., \& Mienis, H. (2006). Middle Paleolithic shell beads in Israel and Algeria. Science, 312, 1785-1788.

Vanhaeren, M., d'Errico, F., van Niekerk, K. L., Henshilwood, C. S., \& Erasmus, R. M. (2013). Thinking strings: Additional evidence for personal ornament use in the Middle Stone Age at Blombos Cave, South Africa. Journal of Human Evolution, 64(6), 500-517.

Vogelsang, R. (1998). Middle-Stone-Age-Fundstellen in Südwest-Namibia, Vol. 11. Köln: Heinrich-Barth-Institut.

Vogelsang, R., \& Eichhorn, B. (2011). Under the mopane tree: Holocene settlement in northern Namibia, Vol. 24. Köln: Heinrich Barth Institut.

Wadley, L. (2009). Post-depositional heating may cause over-representation of red-coloured ochre in stone age sites. South African Archaeological Bulletin, 64(190), 166-171.

Watchman, A. L., \& Mazel, A. D. (2003). Dating rock paintings in the uKhahlamba-Drakensberg and the Biggarsberg, KwaZulu-Natal, South Africa. Southern African Humanities, 15(1), 59-73.

Webley, L. (2005). Hideworking among descendants of Khoekhoen pastoralists in the Northern Cape, South Africa. In L. Frink \& K. Weedman (Eds.), Gender and hide produc-tion (pp. 153-174). New York: Altamira.

Wendt, W. (1972). Preliminary report on an archaeological re-search program in south West Africa. Cimbebasia, 2(1), 1-61. Wright, K. (1992). A classification system for ground stone tools from the prehistoric Levant. Paléorient, 18(2), 53-81. 